\title{
Experimental Study on the Damage of Bridge Pier under the Impact of Rockfall
}

\author{
XinPoSun, ${ }^{1}$ YuZhang Bi $\left(\mathbb{D},{ }^{2,3}\right.$ RuoYun Zhou $\mathbb{D}^{\mathrm{D}},{ }^{4}$ HouZhen Zhao, ${ }^{5}$ Xian-Lei Fu ${ }^{(\mathbb{D})}{ }^{2}$ Pu Zhao, ${ }^{6}$ \\ and Zhe-Yuan Jiang ${ }^{3,2}$ \\ ${ }^{1}$ College of Civil Engineering, Sichuan University of Science and Engineering, Zigong 643000, China \\ ${ }^{2}$ B-Z Geotechnical Technology (Nanjing) Co., Ltd., Nanjing, Jiangsu 210096, China \\ ${ }^{3}$ Jiangsu Key Laboratory of Urban Underground Engineering \& Environmental Safety, Institute of Geotechnical Engineering, \\ Southeast University, Nanjing, Jiangsu 210096, China \\ ${ }^{4}$ Hunan Polytechnic of Water Resources and Electric Power, Changsha, Hunan 410100, China \\ ${ }^{5}$ NCICT Organization, Beijing 100101, China \\ ${ }^{6}$ Urban and Rural Planning Bureau of Guangyuan City, Guangyuan 628017, Sichuan, China
}

Correspondence should be addressed to YuZhang Bi; byz690@yeah.net and RuoYun Zhou; zhoury1026@163.com

Received 26 October 2020; Revised 31 January 2021; Accepted 16 February 2021; Published 11 March 2021

Academic Editor: Melina Bosco

Copyright (c) 2021 XinPo Sun et al. This is an open access article distributed under the Creative Commons Attribution License, which permits unrestricted use, distribution, and reproduction in any medium, provided the original work is properly cited.

In this paper, a discussion is presented about the impact-induced damage suffered by bridge pier columns during rockfall events through model tests and impact force, column top displacement, stress-strain response, and other parameters in relation to the process of impact. On this basis, the following conclusions are drawn. Firstly, the impact force, as well as the displacement and strain of the column top, increases rapidly after taking a hit, while the displacement is reduced after reaching its maximum. Secondly, at the same falling height, the higher the impact position, the smaller the peak of impact force and the longer the attenuation period. Thirdly, at the same impact height, the impact energy, the displacement of the column top, and the peak of the impact force increase as the falling height of the pendulum ball is on the rise, but the attenuation period remains unchanged. Fourthly, the failure mode of column impacted by the swing ball conforms to shear-flexural failure. Fifthly, it is recommended to strengthen the preventative measures for those weak positions like $1 / 2$ height and $1 / 4$ height of bridge pier, so as to minimize the potential damage caused by rockfalls. Besides, a theoretical formula used to estimate the maximum impact force is proposed. Lastly, under the axial load of bridge deck, the performance of the pier in impact resistance under rockfall is better and the damage is less severe than in the experimental impact test. The axial load applied by the deck imposes some constraints on the pier, thus reducing concrete damage. The research results can contribute to the research on addressing the rockfall-bridge pier collision problem. The experimental research demonstrates its theoretical significance to engineering for the prevention of rockfall.

\section{Introduction}

In recent years, with the rapid expansion of transportation network across China, the earthquake-prone areas distributed in mountainous regions provide favorable conditions for the occurrence of rockfall incidents [1-4]. When rockfall disaster happens, the bridge piers might take a hit, which will cause serious damage to highway bridges. Therefore, for the highway bridges constructed in the areas with favorable conditions for rockfall incidents to occur, rockfall-bridge pier collision is a major problem worthy of careful consideration. With regard to the industry standards applied in China, however, the regulations on protecting bridge piers from the impact of rockfall have not been proposed yet. In order to promote the development of bridge construction in China and reduce the detrimental effects caused by rockfall disasters, it is of much practical significance to figure out the dynamic response mechanism and pier damage caused by rockfall-bridge pier collision, which is conducive to mitigating the risk of rockfall 
impacting on the bridge and improving its ability to withstand rockfall [5-7].

In prior studies, there have been various methods proposed for the identification of structural damage, for example, the numerical simulation based on Johnson-Cook model [8] and the damage location method intended for engineering structures [9]. However, most of them involve only numerical simulation or simple laboratory models, which leads to a lack of practical application in the field of engineering. In general, for future studies, consideration shall be given to how to collect more stable signals in the monitoring process and how to locate the damage more accurately.

In respect of bridge pier collision, most of prior research focuses on waterway vessels and highway vehicles collision. The main research methods are shown as follows. In addition to the widely used impulse theorem, [10] proposed the energy method to study ship-ship collision. By means of energy conversion, the impact force generated by the collision was fitted to find out about the linear coupling relationship between the deformation to rigid body and the impact energy received, namely, the Minosky curve. In order to calculate the impact force, collision frequency, and bending shear wave velocity of the hull, [11] analyzed and summarized the empirical expressions. When it comes to numerical solution, finite element software LS-DYNA is commonly applied to conduct mechanical analysis and simulation for the dynamic response of structures under impact loads [12]. Model test research [13] is regarded as the most direct and effective method to address ship-bridge collision. The data collected can not only provide guidance on numerical simulation and theoretical exploration, but also verify the scientific nature of theoretical exploration and numerical simulation.

As for the research on rockfall-bridge pier collision, numerical analysis is conducted in most cases [14-16]. For example, [14] proposed a novel structure intended for protecting bridge pier, which proved effective in mitigating rockfall impact and significantly improving the performance of bridge piers in withstanding impact. As demonstrated by [16], the Holmquist-Johnson-Cook constitutive model could be applied to simulate the behavior of concrete under impact load. Lu and Zhang [15] conducted discussion about the influence caused by the direction of impact loading, impact position, and characteristics of impact load on the mechanical performance of bridge piers. In summary, it is rare to use model test for the study of rockfall-bridge pier collision, and there is a necessity to explain the dynamic response of collision and the pattern of damage.

The aforementioned research methods started from shipship collisions $[17,18]$ and were gradually extended to shipbridge collision $[19,20]$. However, there was little attention paid to the study of rockfall-bridge pier collision. At present, certain achievements have been made in the study of reinforced concrete structures subjected to impact from rockfalls. Mougin et al. [21] conducted model test to investigate the impact of falling rock on concrete shed. Taking into consideration the plastic effect of reinforced concrete slabs under impact, [22] explored the dynamic response of slabs. The studies in $[23,24]$ and [25] developed different calculation formulas for the impact force of rockfall through many experiments.
Though the principle of ship-bridge collision research shows similarity to that followed by rockfall-bridge pier collision, the rockfall-bridge pier collision is more complex, which is attributed to the consideration given to rigidity, the quality of the rock and pier, the physical properties of inclined overburden, and the speed of rockfall. In addition, pier damage is closely associated with the pattern of collision contact and the impact position of rock, thus involving a variety of complex nonlinear phenomena [26, 27]. Therefore, it is essential to study the dynamic response and damage mode of rockfall-bridge pier collision.

At present, rockfall disaster poses severe threat to the safe operation of highway bridges in China. Whether at home or abroad, most studies focus attention on ship-bridge and car-bridge collisions, with only limited attention paid to the dynamic response of rockfall-bridge pier, which makes it necessary to conduct further exploration. In this paper, a $56 \mathrm{~kg}$ pendulum ball device is designed to impact on a $1 / 4$ scale concrete model column, which is purposed to simulate a rockfall impacting a bridge pier. On this basis, a discussion is conducted about the dynamic response and damage mode of rockfall-bridge pier collision through the time-history curves of impact force, velocity, acceleration, pier top displacement, stress-strain, and other parameters related to the process of impingement, along with the crack condition of the column.

\section{Experimental Model and Methods}

2.1. Project Background. As can be seen from Figure 1, the project relied on in this paper is the Chediguan bridge $\left(103^{\circ} 29^{\prime} 45^{\prime} E, 31^{\circ} 13^{\prime} 22^{\prime} \mathrm{N}\right)$ located at $\mathrm{K} 44+235$ of national highway 213 in Wenchuan county, Aba prefecture, Sichuan province [28]. It is an assembled I-beam +hollow slab structure, and the substructure is a double-column pier. In the Wenchuan earthquake on May 12, 2008, Chediguan bridge was smashed by rockfalls, and the road was paralyzed, as shown in Figure 2(a). After erecting the steel frame bridge for repair, a year later, the bridge completely reopened to traffic. A few months later, another landslide occurred in the area where the Chediguan bridge was located. The total volume of the collapse exceeded $10000 \mathrm{~m}^{3}$, including the largest block of boulders over $50 \mathrm{t}$ falling, which completely smashed part of the bridge piers and caused the collapse of the $100 \mathrm{~m}$ long bridge deck. The source and the accumulation area of the collapse, and the movement trajectory are shown in Figure 2(b). The collapse is about $1000 \mathrm{~m}$ long and 200-280 m wide, located on the right bank of Minjiang river, on the left side of Chediguan bridge, with a relative height difference of nearly $700 \mathrm{~m}$; the surface of rock mass is broken, and joints and fissures are well developed.

Columns as the axial load carrying structural members in bridge piers are inherently at the risk of lateral impact loads during the rockfall collision events. In the case of Chediguan bridge, it can be seen that the rockfall disaster caused severe damage to the bridge piers which caused not only the deck collapse and road paralysis, but also property loss and damage to the environment. 


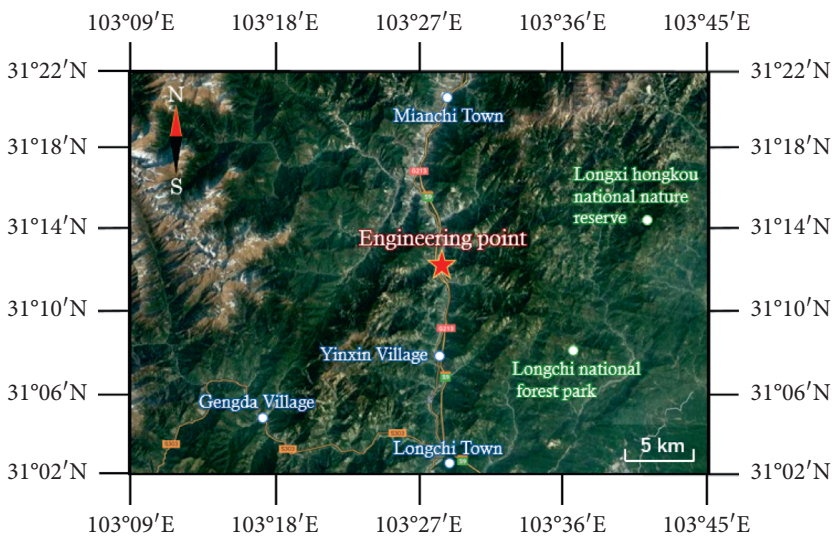

Figure 1: Location of Chediguan bridge.

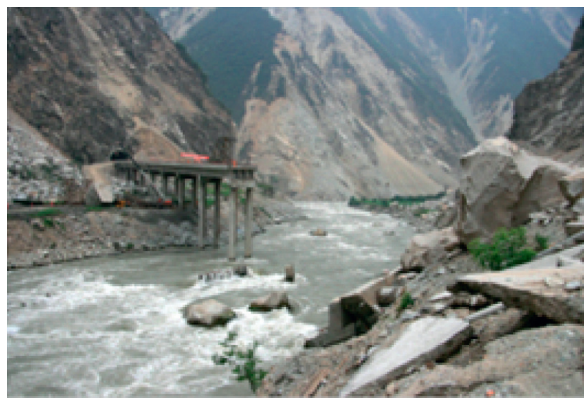

(a)

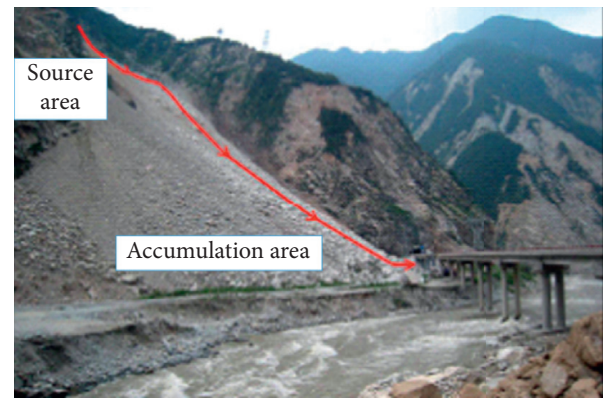

(b)

FIGURE 2: Rockfalls smashed up the bridge: (a) rockfalls smashed Chediguan bridge; (b) the 2nd time rockfalls smashed Chediguan bridge.

Therefore, based on the background of the project, this paper studied the dynamic response mechanism and damage of a rockfall hitting the bridge pier by carrying out indoor model tests.

2.2. Model Test Design. The experimental site is located in the structure laboratory of Southwest University of Science and Technology in Sichuan, China. Relying on the large reaction wall in the laboratory, the experiment adopted the principle of single pendulum (Figure 3) to carry out the test of rockfall-bridge pier collision. The components of experiment equipment are as follows:

(1) Model column

(2) Pendulum ball device

(3) Test instruments

(4) Position arrangement of each measuring point

2.2.1. Model Column. The prototype of this test was a high double-column bridge pier with circular cross section $(R=1.2 \mathrm{~m}, H=10 \mathrm{~m})$. C30 concrete was adopted to make a cylindrical reinforced concrete model bridge pier with a diameter of $300 \mathrm{~mm}$ and a height of $2500 \mathrm{~mm}$ with a scaling ratio of $1: 4$. The schematic diagram of the model is shown in Figure 4, and the preparation of experiment materials is

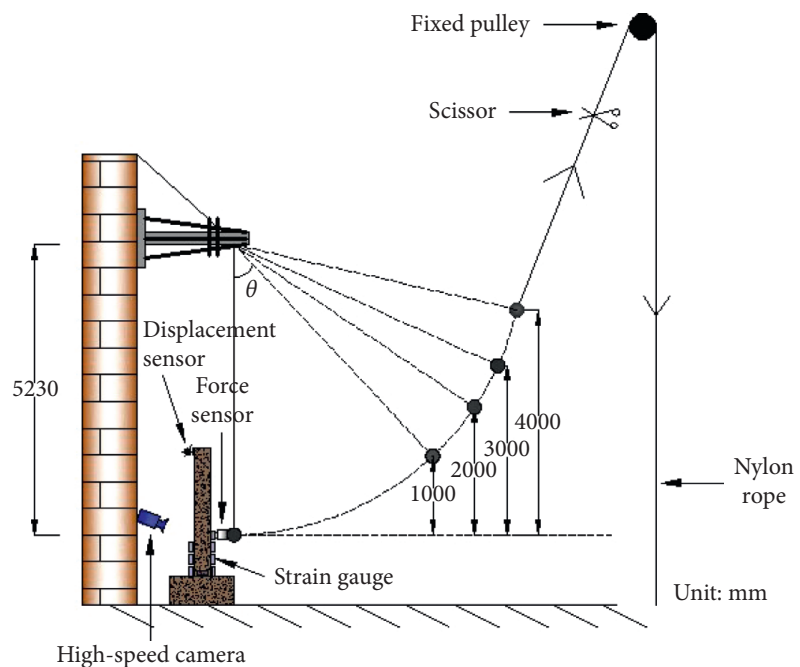

Figure 3: Experimental schematic diagram.

shown in Table 1. The material mechanical properties of the column are tabulated in Table 2 .

In order to assemble the experimental device, the reserved holes were designed to anchor the model column. The reserved hole size is shown in Figure 5.

The ratio of the longitudinal reinforcement of the model column was $0.71 \%, 10$ pieces of HPB300 round steel with a diameter of $8 \mathrm{~mm}$ were uniformly set on the circumference 

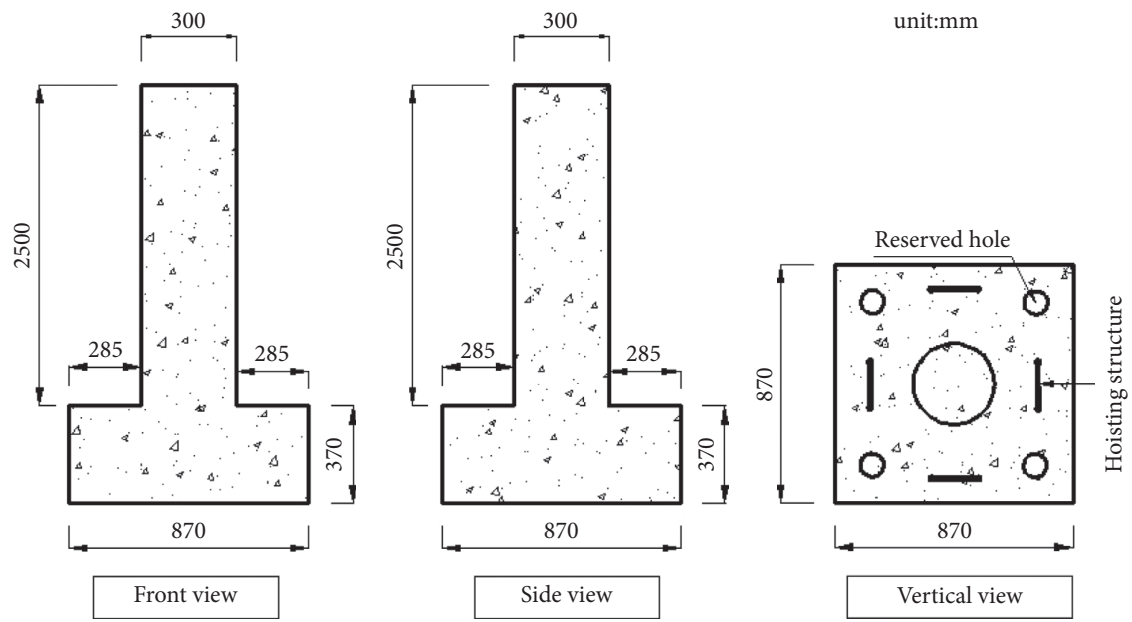

FIgURE 4: Schematic diagram of the model column.

TABLE 1: Experimental materials of the model column.

\begin{tabular}{|c|c|c|c|c|}
\hline Category & Type & Material & Size $(\mathrm{mm})$ & Quantity \\
\hline \multirow{3}{*}{ Model frame } & (1) Model column & $\begin{array}{l}\text { PVC plastic dam- } \\
\text { U315 }\end{array}$ & $R=300 ; H=2500$ & 3 \\
\hline & (2) Base & Steel and wood & $\begin{array}{l}870 \times 870 \times 370 \\
(\text { length } \times \text { width } \times \text { height })\end{array}$ & - \\
\hline & (3) Reserved holes & $\begin{array}{l}\text { PVC plastic } \\
\text { dam-U75 }\end{array}$ & $L=800$ & 4 \\
\hline \multirow{4}{*}{ Reinforcement } & $\begin{array}{l}\text { (1) Column longitudinal } \\
\text { reinforcement }\end{array}$ & НРB300 & $10 \mathrm{C} 8$ & $\begin{array}{l}3.15 \mathrm{~m} \times 10 \text { pieces } \times 3 \\
\text { groups }\end{array}$ \\
\hline & $\begin{array}{l}\text { (2) Column transverse } \\
\text { reinforcement }\end{array}$ & CRB550 & A4 & $45 \mathrm{~m}$ \\
\hline & (3) Reinforcement of the base & HRB335 & $\mathrm{C} 16$ & $90 \mathrm{~m}$ \\
\hline & (4) Hoisting construction & HRB335 & $\mathrm{B} 22$ & $18 \mathrm{~m}$ \\
\hline \multirow{3}{*}{ Concrete } & (1) Cement & $\begin{array}{l}\text { 325\# portland } \\
\text { cement }\end{array}$ & -- & $1.48 \mathrm{~m}^{3}, 658 \mathrm{~kg} / \mathrm{m}^{3}$ \\
\hline & (2) Sand & $\begin{array}{l}\text { Medium (coarse) } \\
\text { sand }\end{array}$ & -- & $1.48 \mathrm{~m}^{3}, 743 \mathrm{~kg} / \mathrm{m}^{3}$ \\
\hline & (3) Gravel & Fine gravel & -- & $1.48 \mathrm{~m}^{3}, 1809 \mathrm{~kg} / \mathrm{m}^{3}$ \\
\hline
\end{tabular}

TABle 2: Material mechanical properties of the column in experiment impact test.

\begin{tabular}{lcc}
\hline Model & Parameter & Value \\
\hline Column concrete & Cube strength (MPa) & 30 \\
Column longitudinal & Yield strength (MPa) & 300 \\
reinforcement & Yield strength (MPa) & 550 \\
Column transverse reinforcement & Yield strength (MPa) & 335 \\
\hline
\end{tabular}

of the column, the spacing of each longitudinal reinforcement bar was $81.64 \mathrm{~mm}$, and the stirrup ratio was $0.898 \%$, the same as that of the prototype. The thickness of the column protective layer was $20 \mathrm{~mm}$, and the reinforcement is shown in Figure 6.

In order to simulate the boundary conditions of the pier base as realistically as possible, a reinforced concrete base of $870 \mathrm{~mm} \times 870 \mathrm{~mm} \times 370 \mathrm{~mm}$ was made at the bottom of the member, with a protective layer of $35 \mathrm{~mm}$. Four bolt holes were reserved, and the model column was fixed and

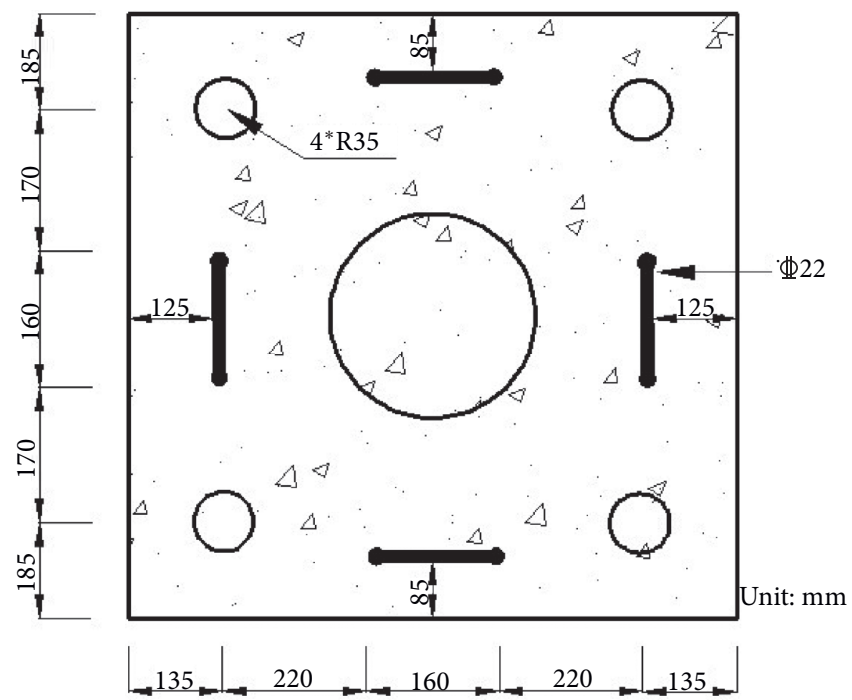

Figure 5: Size of reserved holes. 


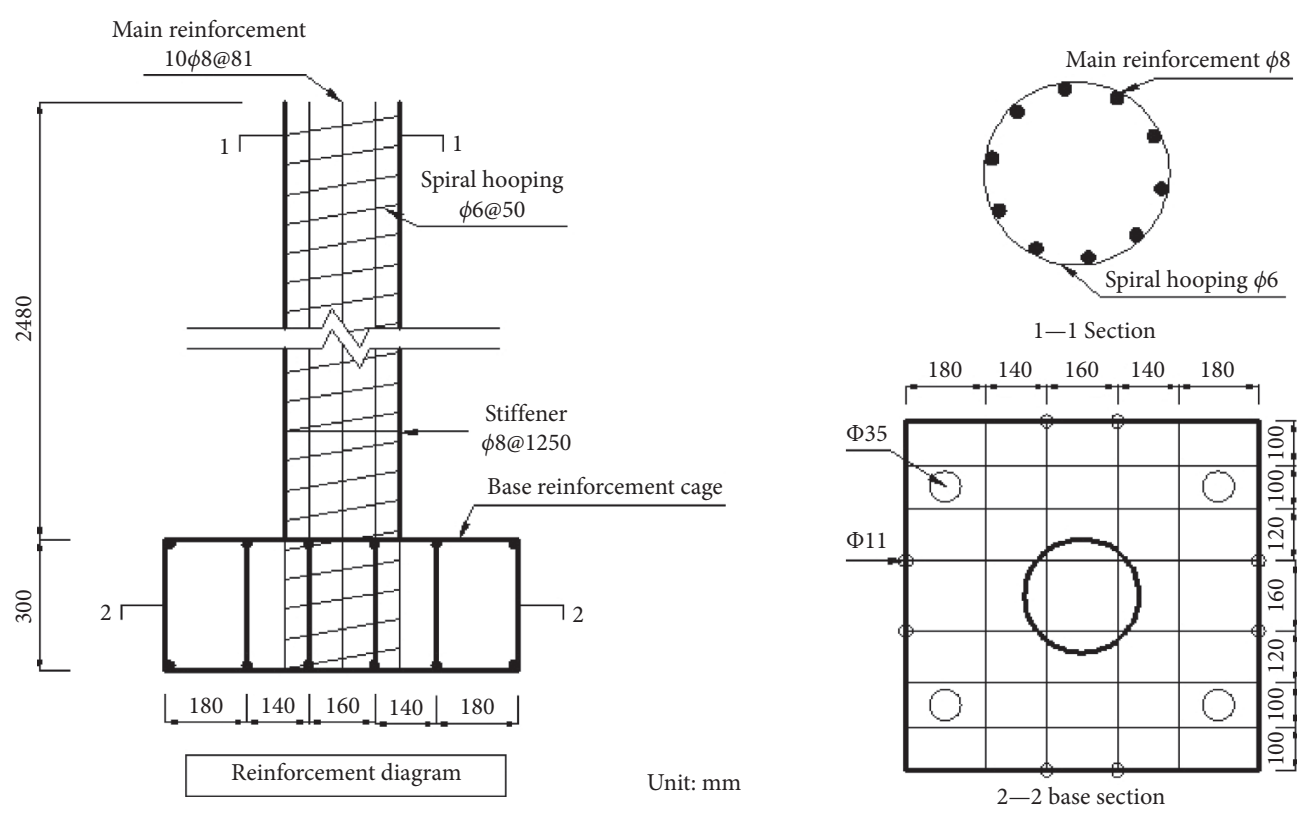

FIgURE 6: Reinforcement of the model column.

restrained on the $1 \mathrm{~m}$ thick reactive floor in the laboratory. The position of the model column during installation and the hole position diagram of the model column during installation are shown in Figure 7.

\subsubsection{Pendulum Ball Device}

(1) Support Beam. The swing rope with diameter of $10 \mathrm{~mm}$ and length of $6.5 \mathrm{~m}$ was fixed on the support beam welded by $\mathrm{H}$-section steel and anchored on the reaction wall. In this test, it is necessary to ensure that the suspended steel ball lightly touched the force sensor on the model column in the static state, so a supporting beam was designed to arbitrarily adjust the position of the pendulum ball in the static state within a certain range. The design and physical drawings are shown in Figures 8 and 9.

(2) Pendulum Ball. A solid steel ball was adopted, with a diameter less than that of the column, a radius of $13 \mathrm{~cm}$, and a mass of $56 \mathrm{~kg}$, as shown in Figure 10. The impact test adopted the point contact mode; that is, the spherical tangential point hit the cylindrical model pier.

(3) Impact Sensor and Spherical Impact Head. The impact sensor used in the experiment is fixed on the spherical impact head by bolts, which can measure the impact value conveniently, quickly, and accurately. The spherical impact head can simulate the impact state of a rockfall and reduce the error, as shown in Figure 11. The final test device is shown in Figure 12.

(4) Sensor Protection Device. The contact form between the sensor and the cylinder was spherical contact. In order to avoid the sensor falling and damaging the sensor, the guard band device was designed as the sensor protection device (Figures 13 and 14).

2.2.3. Positions of Measuring Points. The positions of rebar strain gauges, impact force sensor, and displacement sensor are shown in Figure 15.

2.2.4. Test Instruments. The test instruments required for the experiment are shown in Table 3.

2.3. Test Methods. The methods of the impact test are as follows:

(1) In terms of impact force measurement, the force sensor on the bearing is used to record the impact time-history curve to obtain the impact value and further calculate the velocity and acceleration parameters

(2) The displacement of the column is measured by the displacement sensor fixed on the top of the pier to obtain the displacement parameters of the pier top

(3) In terms of impact process, high-speed cameras are arranged on the side of the specimen to record the whole process of collision and failure

(4) In terms of stress-strain relationship, by sticking the strain gauge at the specified position of the column, the stress-strain relationship of the sticking place was recorded

(5) In terms of the scope of damage of concrete piers, the drawn grid around the impact point is used to record the shape and scope of damage after impact, which is conducive to statistics 


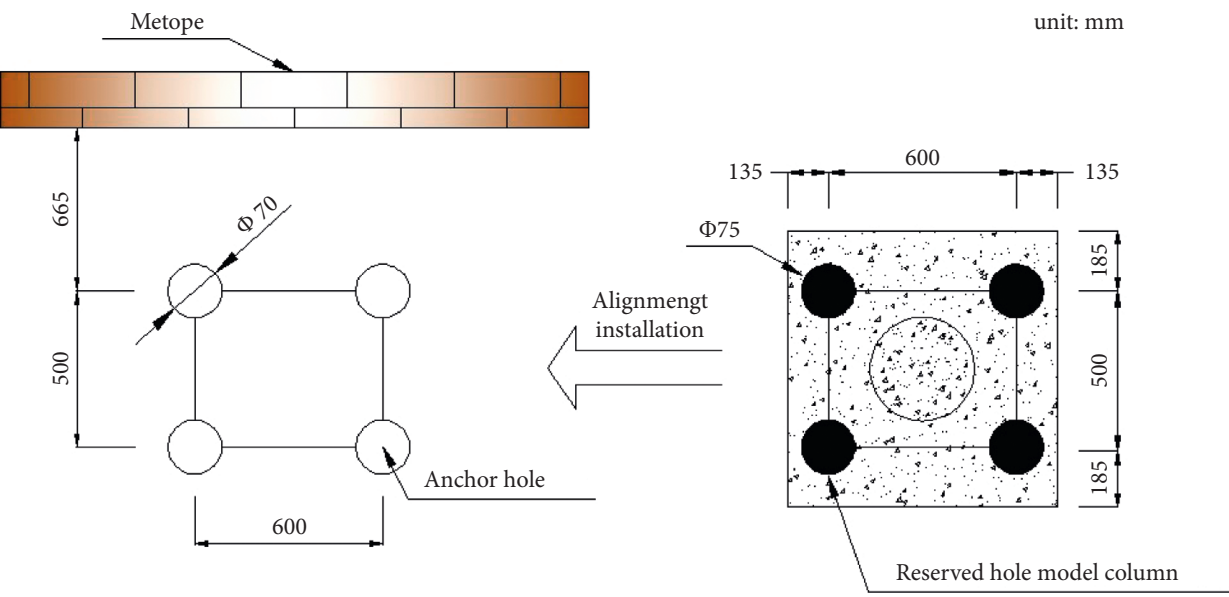

FIGURE 7: Installation of the model column.

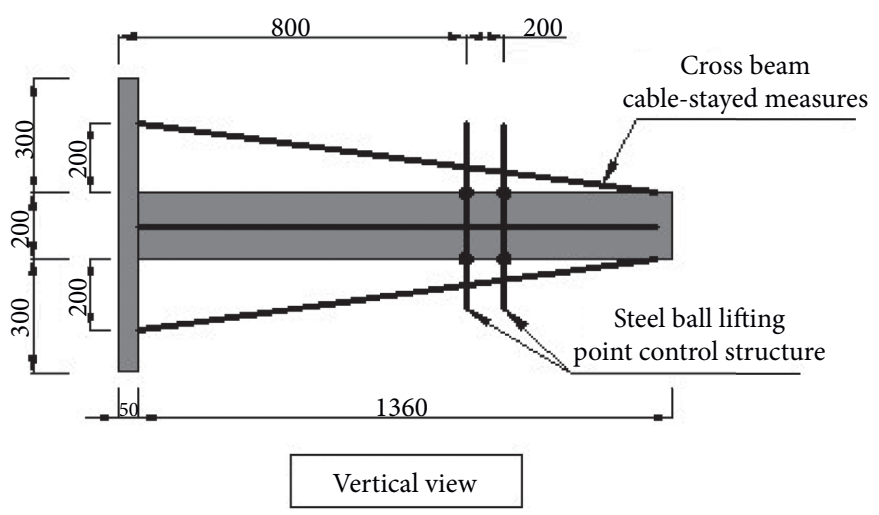

Unit:mm
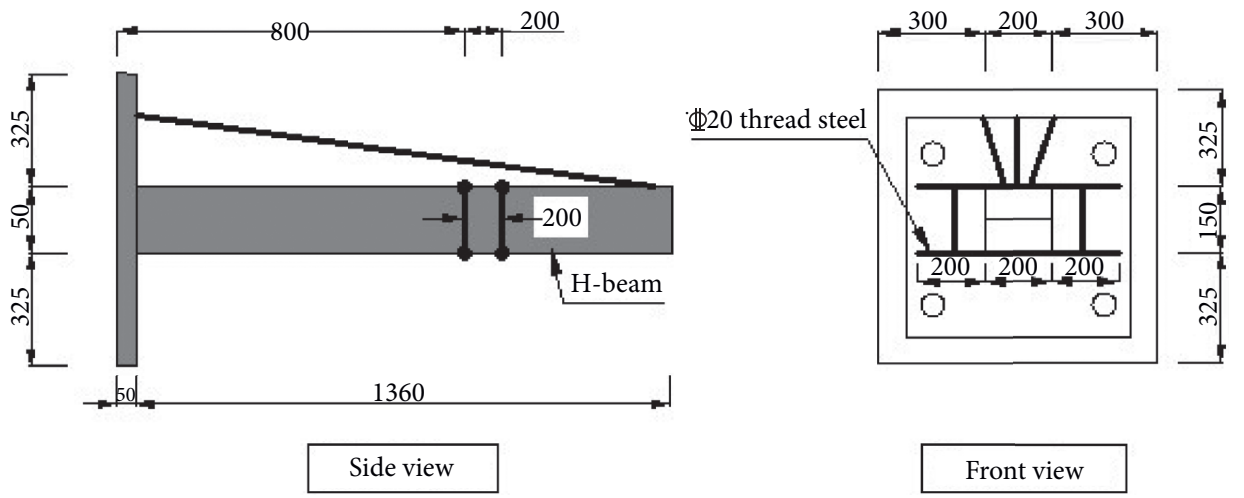

FIgURE 8: Design of the support beam.

\section{Test Details}

There are three groups of experiments, and each group corresponds to one impact height of a reinforced concrete model column, respectively, $1 / 4,3 / 8$, and $1 / 2$ height of the column, named $S_{4 \cdot 1}, S_{8.3}$, and $S_{2.1}$. In each group of experiments, the angle $\theta$ of the swing rope can be changed so that the swing ball hits the model column at the falling heights of $1 \mathrm{~m}, 2 \mathrm{~m}, 3 \mathrm{~m}$, and $4 \mathrm{~m}$, numbered $\mathrm{S}_{4.1-1}{ }^{--} \mathrm{S}_{4.1-4}$. The schematic diagram of different falling heights and impact positions is shown in Figure 16. The peak values and crack conditions of each parameter during each impact are recorded in Table 4.

\section{Result Analysis}

\subsection{Dynamic Response Analysis}

4.1.1. Variation of the Impact Force of the Same Height of the Column under Different Falling Heights. The variation of impact force changing with time under different falling heights of the swing ball hitting $1 / 4$ height of column is 


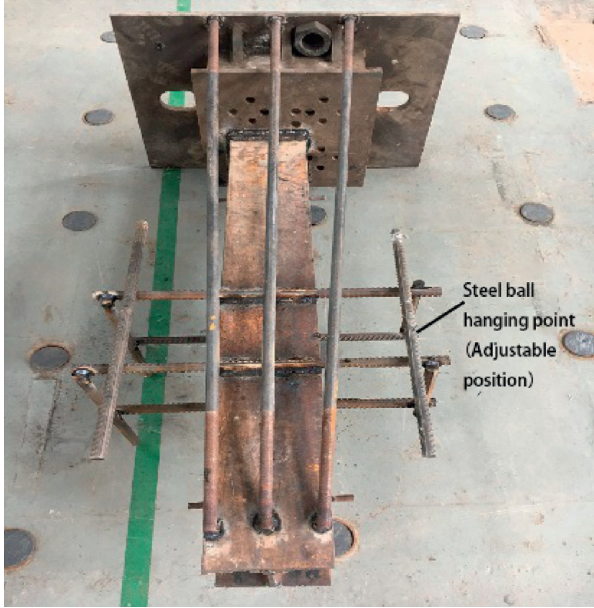

FIgURE 9: Support beam.

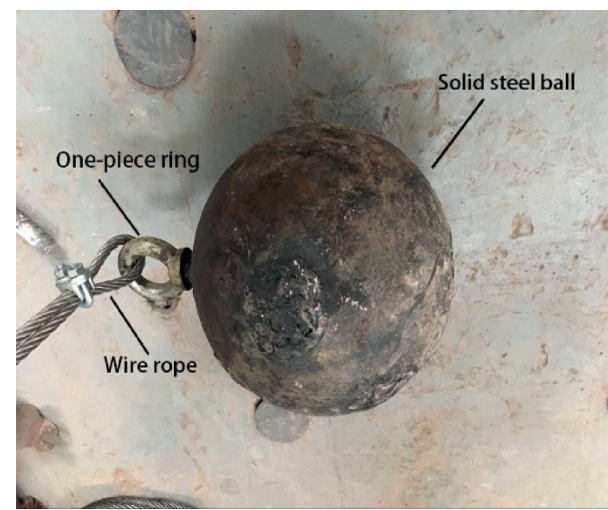

Figure 10: Pendulum ball.

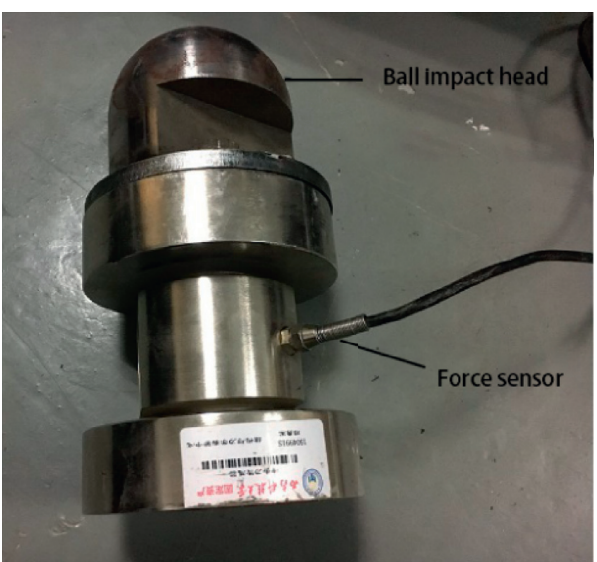

FIgURE 11: Impact sensor and spherical impact head.

shown in Figure 17. It can be found that after hitting the column, the impact force reached the peak at about $1 \mathrm{~ms}$. With the increase of time, the impact force between the column and the swing ball gradually decreased to zero. When the falling height of the pendulum ball was $1 \sim 4 \mathrm{~m}$, the peak of impact force of the four working conditions is

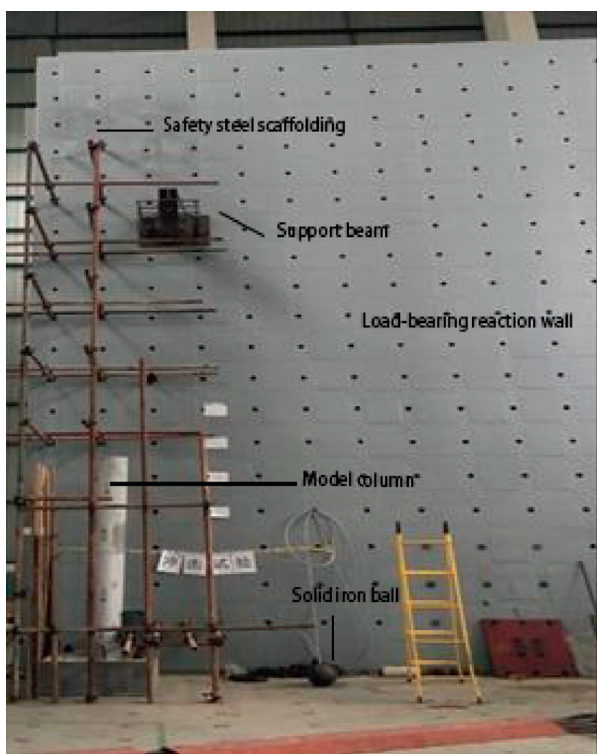

Figure 12: Final test device.

$123.96 \mathrm{kN}, 175.31 \mathrm{kN}, 214.71 \mathrm{kN}$, and $247.92 \mathrm{kN}$, respectively. For every $1 \mathrm{~m}$ increase in the falling height of the pendulum ball, the peak of impact force increased by $41.4 \%$, $22.5 \%$, and $15.5 \%$, respectively, and the growth rate kept a decreasing trend. Moreover, for every $1 \mathrm{~m}$ increase in the falling height of the pendulum ball, the growth of the peak impact force periodically attenuated, and the growth rate continuously decreased.

The peak of impact force increased with the increase of the falling height of the pendulum ball. Through polynomial fitting, its functional relation satisfied the following formula:

$$
F_{\max }=0.96 h_{b}^{3}-11.735 h_{b}^{2}+79.835 h_{b}+54.9\left(1 \leq h_{b} \leq 4\right) .
$$

In the formula, $F_{\max }$ represents the peak impact force, and $h_{b}$ refers to the falling height of the pendulum ball.

4.1.2. Variation of the Impact Force of the Column at the Same Falling Height under Different Impact Heights. Figure 18 shows the influence of the impact heights of the column on the impact force at the same falling height of the swing ball. The impact force of $S_{8.3-1}$ and $S_{2.1-1}$ bridge piers took $1.1 \mathrm{~ms}$ and $1.3 \mathrm{~ms}$, respectively, from zero to the peak, increasing by 1.2 times. The peak impact force of the column in the two conditions was $82.64 \mathrm{kN}$ and $61.98 \mathrm{kN}$, respectively, reducing by 1.3 times. It can be found that the impact force declined with the growth of the height of the hitting, and the relationship between the maximum impact force and the height of the column is polynomial, as shown in

$$
F_{\max }=661.12 h_{b}^{2}-743.76 h_{p}+268.58\left(0<h_{p}<1\right),
$$

where $F_{\max }$ represents the peak impact force and $h_{p}$ refers to the impact height. 


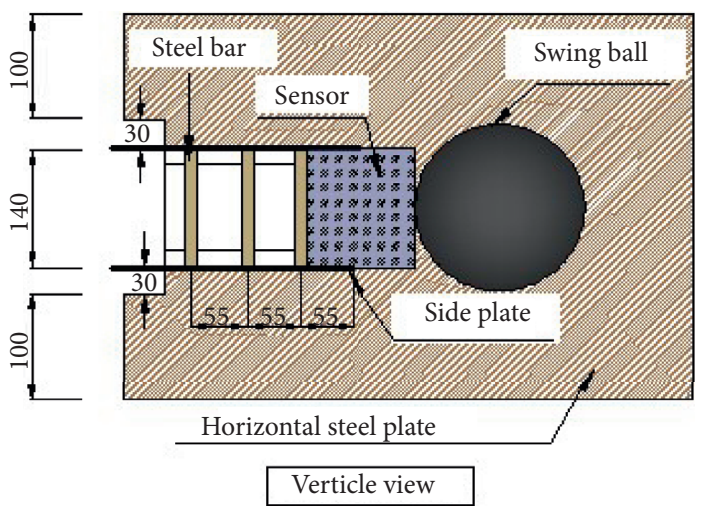

Unit: $\mathrm{mm}$
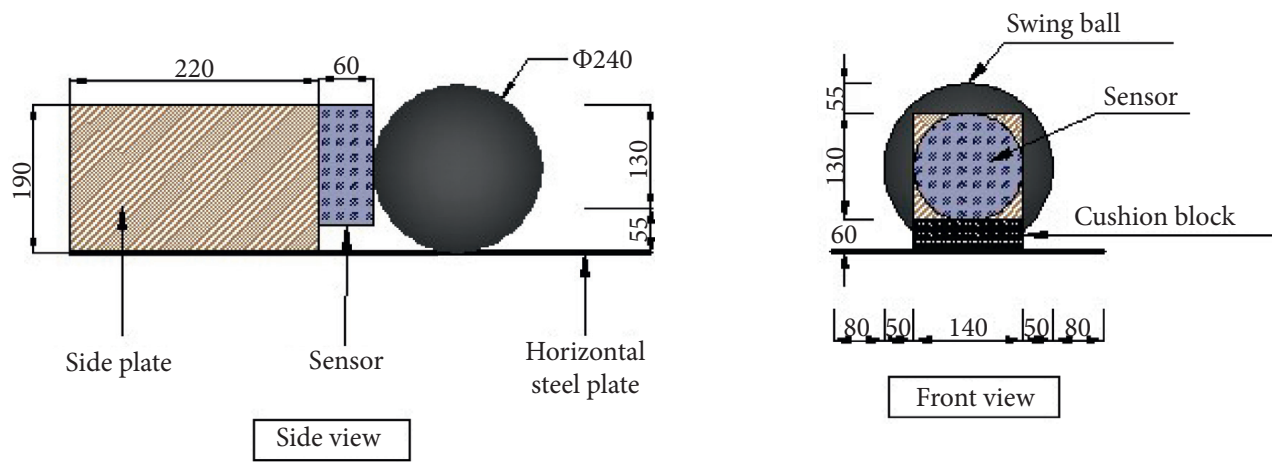

Figure 13: Design of sensor protection device.

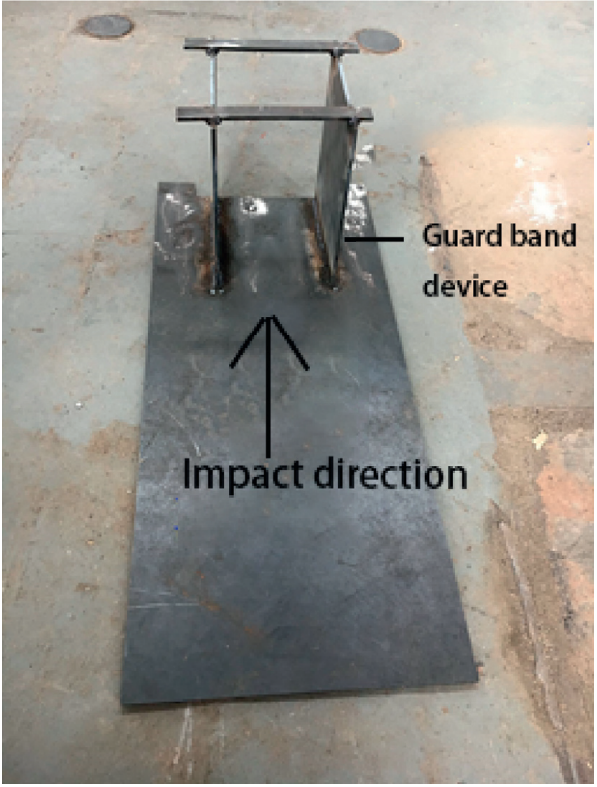

FIGURe 14: Guard band device.

4.1.3. Variation of Column Top Displacement under Different Impact Heights. Figure 19 reflects the variation of the displacement of the column top under different falling heights of the swing ball. $S_{8.3-1} \sim S_{8.3-4}$ reached the maximum pier top displacement in the direction of impact within $2 \mathrm{~ms}$ after impact, and the corresponding peaks were successively $4.6 \mathrm{~mm}, 8.6 \mathrm{~mm}, 17 \mathrm{~mm}$, and $48.5 \mathrm{~mm}$. The relation between peak displacement of column top and falling height of the pendulum ball is shown in

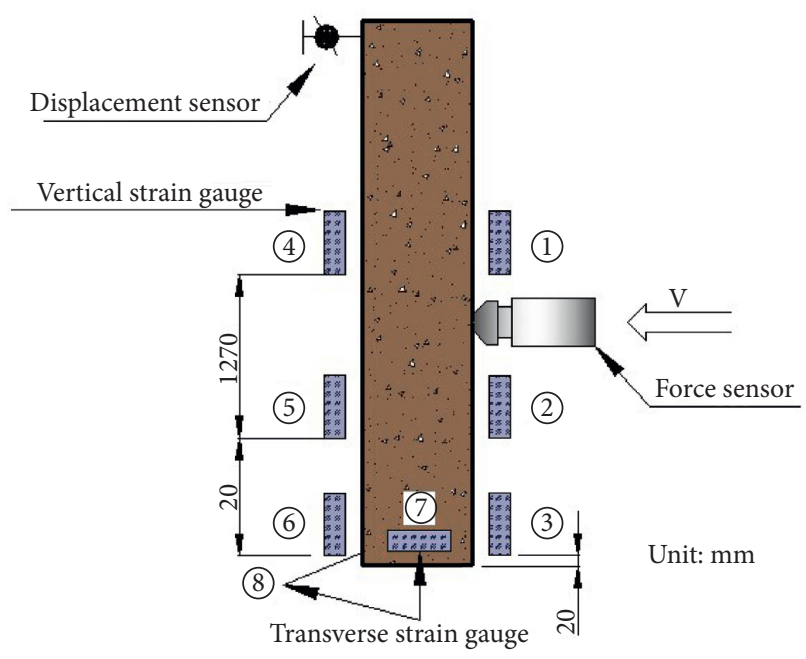

Figure 15: Positions of measuring points of the column.

$$
X_{\max }=3.1167 h_{b}^{3}-16.5 h_{b}^{2}+31.683 h_{b}-13.7\left(1 \leq h_{g} \leq 4\right),
$$

$X_{\max }$ represents the peak displacement of the column top, and $h_{b}$ refers to the falling height of the pendulum ball.

With the increase of the falling height of the swing ball, the maximum displacement of the column top caused by the impact also increased from $1 \mathrm{~m}$ to $4 \mathrm{~m}$, with a growth rate of the maximum displacement of $87 \%, 97.7 \%$, and $185.3 \%$, respectively, maintaining a trend of continuous increase. When the peak of column top displacement was reached, the column top displacement decayed to zero periodically, with each period being approximately $0.6 \mathrm{~ms}$. 
TABLE 3: Test instruments introduction.

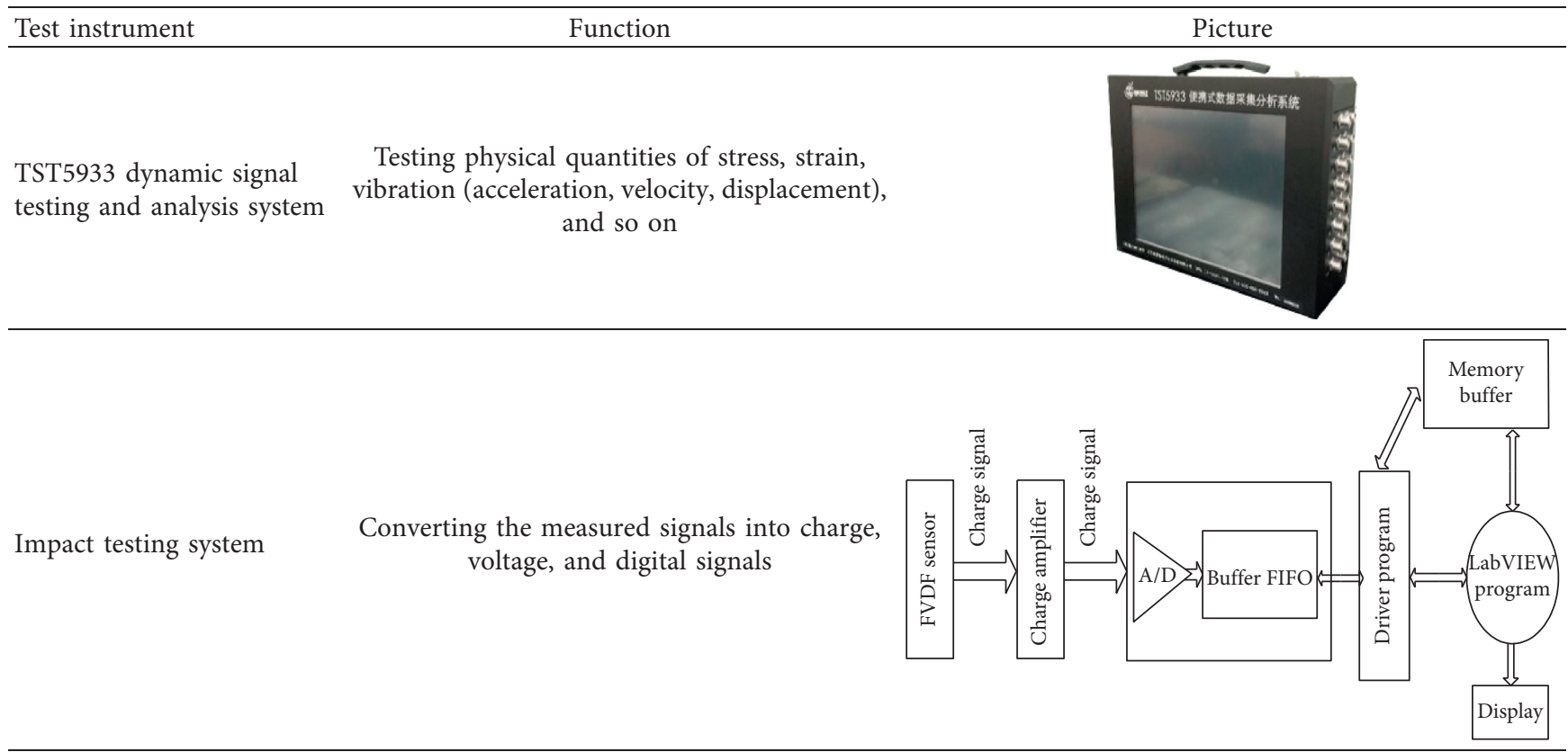

YHD displacement sensor Converting electric quantity into displacement
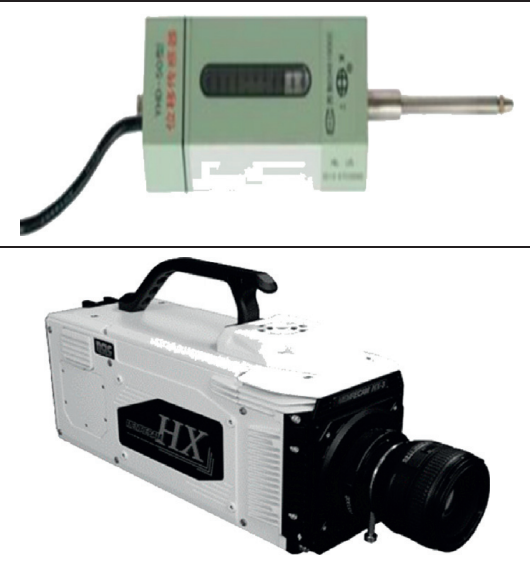

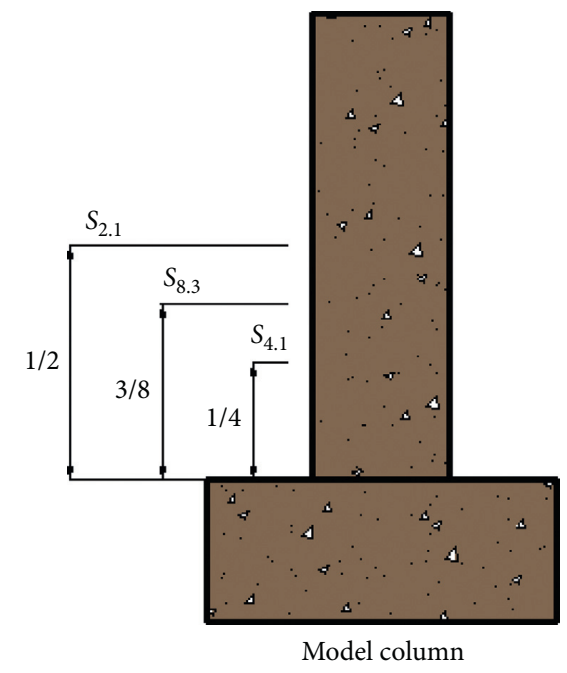

FIGURE 16: Schematic diagram of model column.
4.1.4. Variation of Column Top Displacement under Different Falling Heights. Figure 20 reflects the variation of displacement of column top under different impact heights. After the impact, the column top displacement increased from zero to the peak value only in $0.5 \mathrm{~ms}$. The displacement of the column top of $\mathrm{S}_{2.1-4}$ was larger, $82.5 \mathrm{~mm}$; the maximum displacement of the $\mathrm{S}_{4.1-4}$ pier was $35.3 \mathrm{~mm}$. After the column top displacement reached the peak, the reverse swing reached the peak, and then the positive and negative periodic attenuation occurred. The attenuation period of $\mathrm{S}_{4.1-4}$ was relatively short, about $0.5 \mathrm{~ms}$. $\mathrm{S}_{2.1-4}$ had a long decay period of about $1 \mathrm{~ms}$.

According to the maximum displacement of the top of the column at different impact heights, the displacement value at $1 / 2$ height of the column was relatively large, indicating that this position was most likely to be damaged by the impact, and the weak position should be strengthened in the design. 
TABle 4: Peak values and crack conditions.

\begin{tabular}{|c|c|c|c|c|c|c|c|}
\hline Specimen & $\begin{array}{l}\text { Falling } \\
\text { height } \\
(\mathrm{m})\end{array}$ & $\begin{array}{l}\text { Hitting } \\
\text { speed } \\
(\mathrm{m} / \mathrm{s})\end{array}$ & $\begin{array}{l}\text { Impact } \\
\text { energy }(J)\end{array}$ & $\begin{array}{l}\text { Column top } \\
\text { displacement } \\
(\mathrm{mm})\end{array}$ & $\begin{array}{c}\text { Maximum } \\
\text { impact force } \\
(\mathrm{kN})\end{array}$ & $\begin{array}{c}\text { Number of } \\
\text { concrete } \\
\text { spalling grids }\end{array}$ & Crack conditions \\
\hline$S_{4 \cdot 1-1}$ & 1 & 4.43 & 548.8 & 4.3 & 123.96 & 1 & $\begin{array}{c}\text { Slight depression at impact, no } \\
\text { obvious crack }\end{array}$ \\
\hline$S_{4 \cdot 1-2}$ & 2 & 6.26 & 1097.6 & 8.2 & 175.31 & 4 & $\begin{array}{l}\text { A horizontal crack } 4 \mathrm{~cm} \text { long and } \\
0.5 \mathrm{~mm} \text { wide began to appear near the } \\
\text { front of the impact point }\end{array}$ \\
\hline$S_{4 \cdot 1-3}$ & 3 & 7.67 & 1646.4 & 17.4 & 214.71 & 17 & $\begin{array}{l}\text { Obvious cracks appeared at the back } \\
\text { of the impact point, and small cracks } \\
\text { also appeared at the upper and lower } \\
20 \mathrm{~cm} \text { near the crack }\end{array}$ \\
\hline$S_{4 \cdot 1-4}$ & 4 & 8.85 & 2195.2 & 35.3 & 247.92 & 44 & $\begin{array}{l}\text { Cracks appeared at the column } \\
\text { bottom, and the small cracks } \\
\text { expanded into cracks. The horizontal } \\
\text { plane of the impact position formed a } \\
\text { penetrating crack, and the large area } \\
\text { of concrete spalled at the impact point }\end{array}$ \\
\hline$S_{8.3-1}$ & 1 & 4.43 & 548.8 & 4.6 & 82.64 & 1 & $\begin{array}{c}\text { The impact point showed sag without } \\
\text { obvious crack }\end{array}$ \\
\hline$S_{8.3-2}$ & 2 & 6.26 & 1097.6 & 8.6 & 116.87 & 3 & $\begin{array}{l}\text { Cracks appeared on the back of the } \\
\text { impact site, and the depression at the } \\
\text { impact site was intensified with crack } \\
\text { propagation }\end{array}$ \\
\hline$S_{8.3-3}$ & 3 & 7.67 & 1646.4 & 17 & 143.14 & 17 & $\begin{array}{l}\text { Obvious cracks began to appear on } \\
\text { the back of the impact point, around } \\
\text { which there were small cracks }\end{array}$ \\
\hline $\mathrm{S}_{8.3-4}$ & 4 & 8.85 & 2195.2 & 48.5 & 165.29 & 43 & $\begin{array}{c}\text { There are cracks in many places of the } \\
\text { column and some cracks in the } \\
\text { bottom }\end{array}$ \\
\hline$S_{2 \cdot 1-1}$ & 1 & 4.43 & 548.8 & 6.4 & 61.98 & 1 & $\begin{array}{c}\text { The impact point showed sag without } \\
\text { obvious crack }\end{array}$ \\
\hline$S_{2 \cdot 1-2}$ & 2 & 6.26 & 1097.6 & 13.6 & 87.65 & 4 & $\begin{array}{l}\text { The horizontal crack appeared near } \\
\text { the impact point, the depression was } \\
\text { intensified, and there are small cracks } \\
\text { on the back }\end{array}$ \\
\hline$S_{2 \cdot 1-3}$ & 3 & 7.67 & 1646.4 & 45.1 & 107.35 & 21 & $\begin{array}{c}\text { An obvious crack appeared on the } \\
\text { back of the impact point, and there } \\
\text { were many small cracks within a } \\
\text { range of } 20 \mathrm{~cm} \text { above and below the } \\
\text { crack }\end{array}$ \\
\hline$S_{2 \cdot 1-4}$ & 4 & 8.85 & 2195.2 & 82.5 & 123.96 & 37 & $\begin{array}{c}\text { A crack appeared at the bottom, and } \\
\text { the previous crack expanded into a } \\
\text { crack }\end{array}$ \\
\hline
\end{tabular}

Note. S4.1-2 means that the pendulum ball hits the height $1 / 4$ of the column with a fall height of $2 \mathrm{~m}$.

It can be seen that, under the same impact height, the higher the falling height of the pendulum ball, the greater the column top displacement, but the attenuation period was the same. The higher the impact height, the larger the column deflection, the greater the maximum displacement of the column in the impact direction, and the longer the decay period after the impact.

4.1.5. Strain Variation. Represented by $\mathrm{S}_{2.1-1}$, the strain at 8 positions of the column was analyzed, and the strain timehistory curves of representative strain gauges (No. 1, No. 4, and No. 5) are listed as shown in Figure 21. The positions and strain characteristics of strain gauges at various positions are shown in Table 5. It can be found that the vertical strain gauge (No. 1, No. 3) near the impact location was under compression. The position on the back side of the column bottom impact surface (No. 4, No. 6) developed the compressive strain; the bottom of the column along the impact was tensile strain (No. 7 and No. 8), which is prone to produce large plastic deformation. The strain value of column top (No. 5) was the minimum in the column and had been in the elastic stage during the whole test.

4.2. Damage Analysis. The damage analysis of each condition is as follows. The injuries of $S_{4.1-1}-S_{4.1-4}$ and $S_{8.3-1}--$ $\mathrm{S}_{8.3-4}$ were concentrated at the impact position, and concrete 


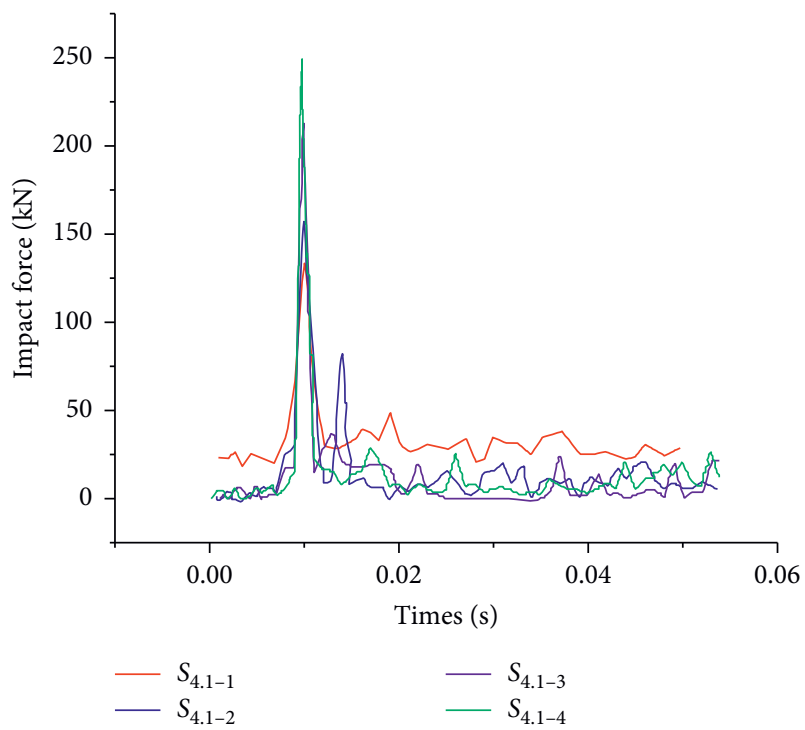

FIGURE 17: Time chart of impact forces at different falling heights of the pendulum ball.

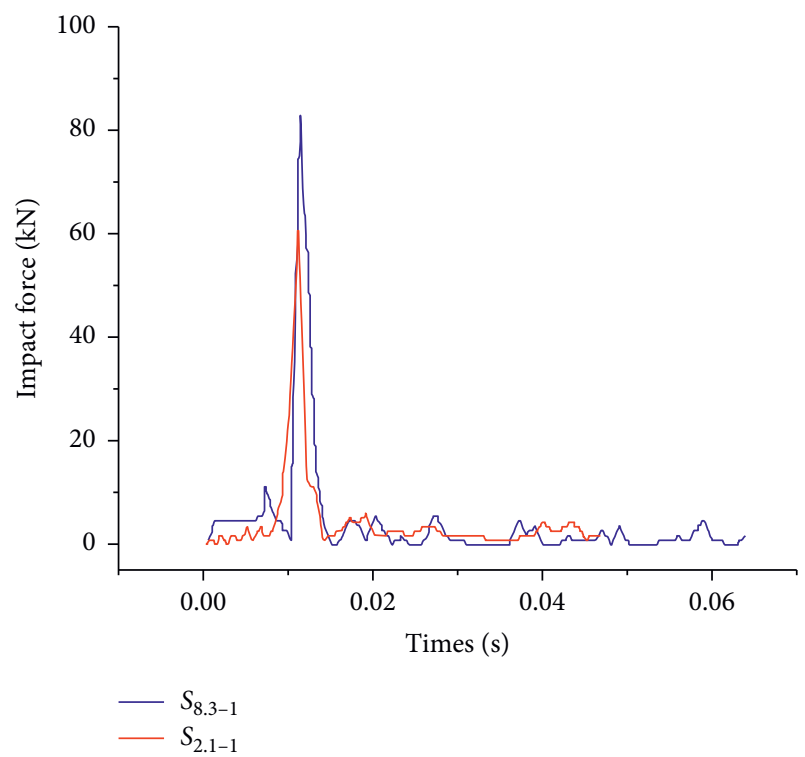

FIGURE 18: Time chart of impact forces at different impact heights of the column.

spalling occurred at the impact position after the impact of the pendulum ball (as shown in Figures 22-25). After impact, surface concrete spalled on the impact position of $S_{2.1-1}$ -- $S_{2.1-4}$, and a small amount of concrete spalled at the column bottom on the back of the impact side of $S_{2.1-4}$ (Figure 25). As can be seen from Figures 21-24, the damage of the impact point of $S_{2.1}$ was the most serious, which can be explained by the fact that the impact height of $S_{2.1}$ was the highest, the kinetic energy of the pendulum was the strongest, and the impact force and impact velocity were also the largest.

Table 6 displays the concrete damage of column for different specimens. Obviously, for the same impact height of a single specimen, the greater the initial falling height of

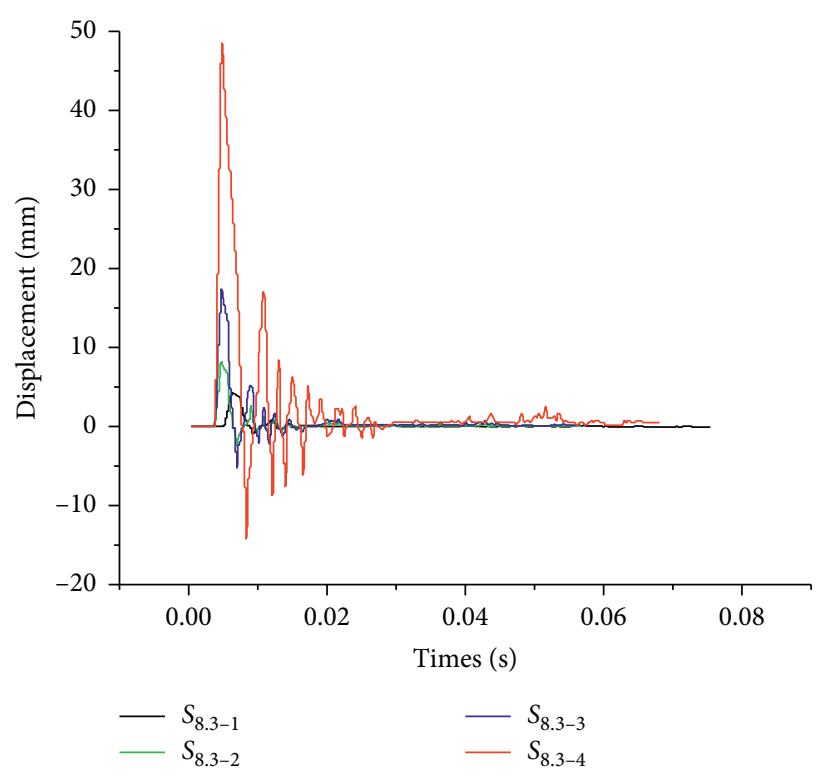

FIgURE 19: Column top displacement chart of impact forces at different falling heights of the pendulum ball.

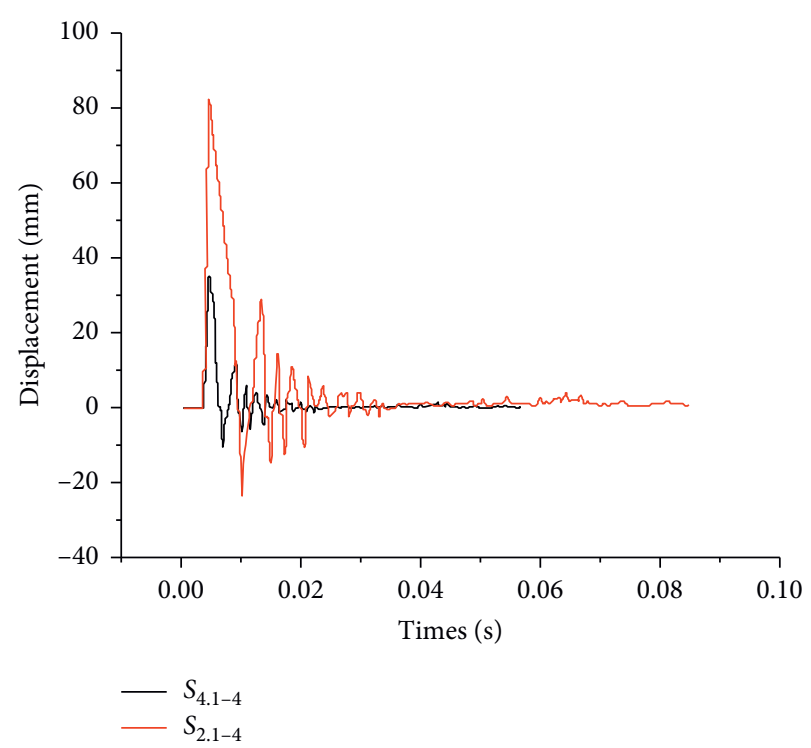

FIgURE 20: Column top displacement chart of impact forces at different impact heights of column.

the pendulum ball (relative height), the more concrete spalling grids at the impact point; that is, with the increase of impact energy, there is more damage to the impact surface. When the initial falling height (relative height) of the pendulum ball increased from $1 \mathrm{~m}$ to $2 \mathrm{~m}$, the number of concrete spalling grids and the growth rate (about $3 / \mathrm{m}$ ) at the impact point of the three specimens were basically the same. When the falling height of the ball increased from $2 \mathrm{~m}$ to $3 \mathrm{~m}$, the number and growth rate of concrete spalling grids at the impact point of $S_{4.1}$ and $S_{8.3}$ were the same $(13 / \mathrm{m})$, while the growth rate of concrete spalling grids at the impact point of $S_{2.1}(17 / \mathrm{m})$ was larger than that of $S_{4.1}$ and $S_{8.3}$. 


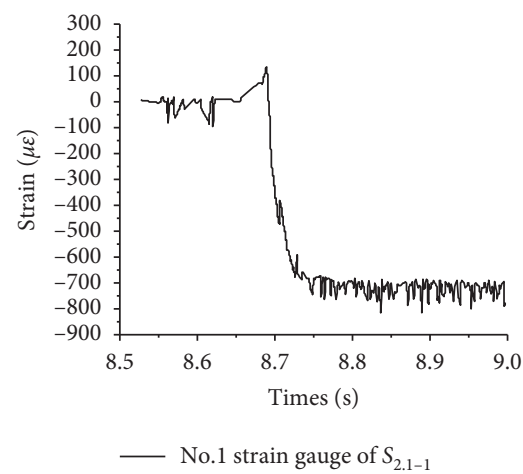

(a)

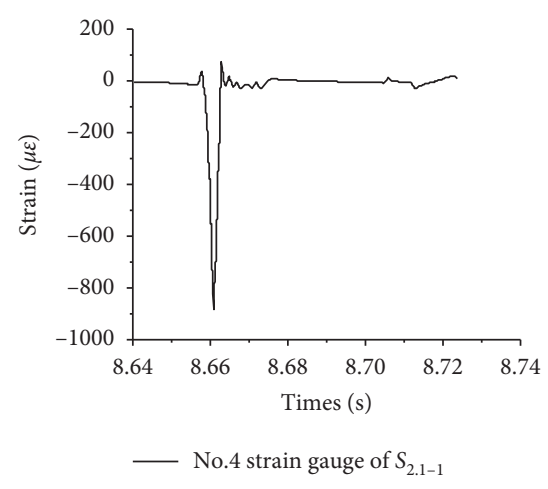

(b)

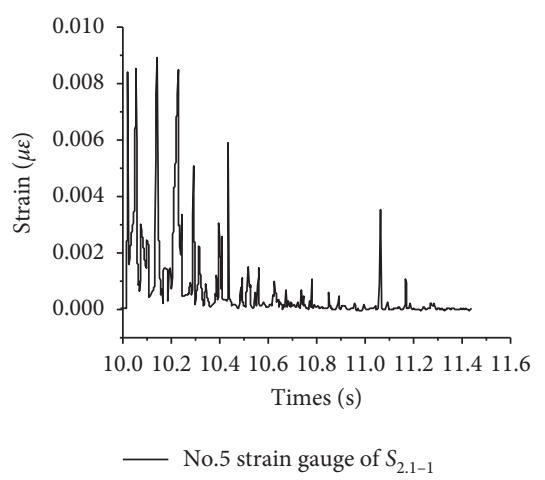

(c)

FIgURE 21: $S_{2.1-1}$ strain time chart of different strain gauges: (a) No. 1 strain gauge; (b) No. 4 strain gauge; (c) No. 5 strain gauge.

TABLE 5: Locations and strain characteristics of strain gauges.

\begin{tabular}{|c|c|c|}
\hline No. & Location & Strain characteristic \\
\hline 1 & $\begin{array}{l}2 \mathrm{~cm} \text { above the impact position, closest to the } \\
\text { impact point }\end{array}$ & Plastic deformation generated \\
\hline 2 & $\begin{array}{l}\text { At the junction of base and bottom of impact } \\
\text { surface }\end{array}$ & $\begin{array}{l}\text { In the state of tension, the compressive strain mutation occurred after impact, } \\
\text { but still in the elastic range }\end{array}$ \\
\hline 3 & At the back of No. 1 strain gauge & $\begin{array}{l}\text { Strain gauge stress increased rapidly and then returned to zero, which belonged } \\
\text { to elastic strain }\end{array}$ \\
\hline 4 & $\begin{array}{l}\text { At the back of the impact position, lower than the } \\
\text { impact position }\end{array}$ & $\begin{array}{l}\text { The strain was very small, several peaks occurred during the second impact of } \\
\text { the pendulum ball and finally returned to zero, and the stress-strain was still } \\
\text { within the elastic range }\end{array}$ \\
\hline 5 & On the back of No. 3 strain gauge & $\begin{array}{l}\text { Under pressure, the compressive strain suddenly occurred after impact, but still } \\
\text { in the elastic range, and the compressive stress was about } 141.4 \mathrm{MPa}\end{array}$ \\
\hline $\begin{array}{l}6 \text { and } \\
7\end{array}$ & $\begin{array}{l}\text { At the junction of the two sides of the column } \\
\text { impact surface and the column base }\end{array}$ & Tensile strain and plastic deformation generated \\
\hline
\end{tabular}

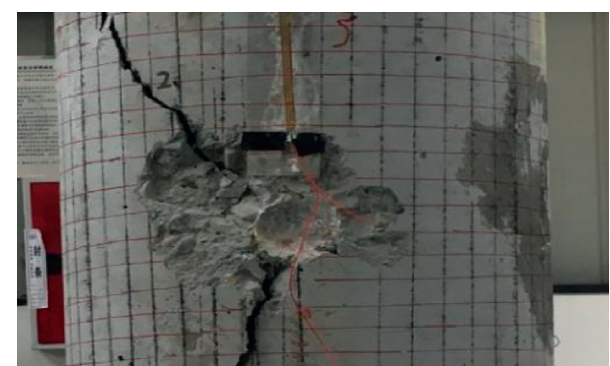

Figure 22: Damage condition of $\mathrm{S}_{4.1}$.

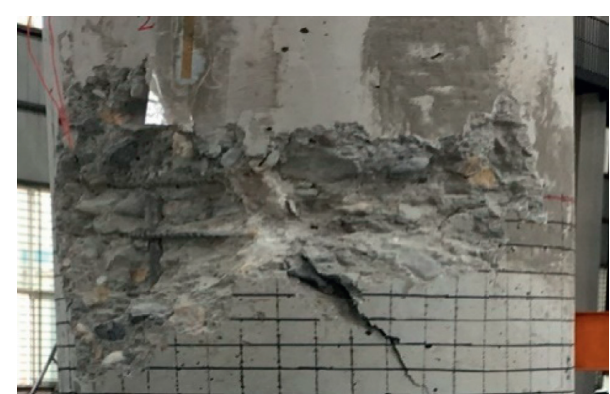

FIGURE 23: Damage condition of $\mathrm{S}_{2.1}$.

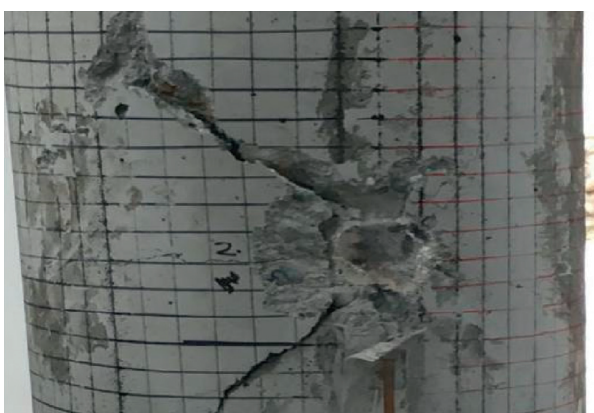

FiguRe 24: Damage condition of $S_{8.3}$.

When the falling height of the ball increased from $3 \mathrm{~m}$ to $4 \mathrm{~m}$, the concrete spalling grids and growth rate $(27 / \mathrm{m})$ of the specimen $S_{4.1}$ and $S_{8.3}$ were still basically the same, the growth rate kept increasing, the growth rate of concrete spalling grids of $\mathrm{S}_{2.1}(16 / \mathrm{m})$ at $4 \mathrm{~m}$ was relatively decreased compared with that at $3 \mathrm{~m}(17 / \mathrm{m})$, and it was less than that at $4 \mathrm{~m}$ of $\mathrm{S}_{4.1}$ and $\mathrm{S}_{8.3}$. Therefore, the number and growth rate of concrete spalling grids of $\mathrm{S}_{4.1}$ and $\mathrm{S}_{8.3}$ kept increasing and reached peak when the initial falling height was $4 \mathrm{~m}$. However, the number of concrete spalling grids at the 


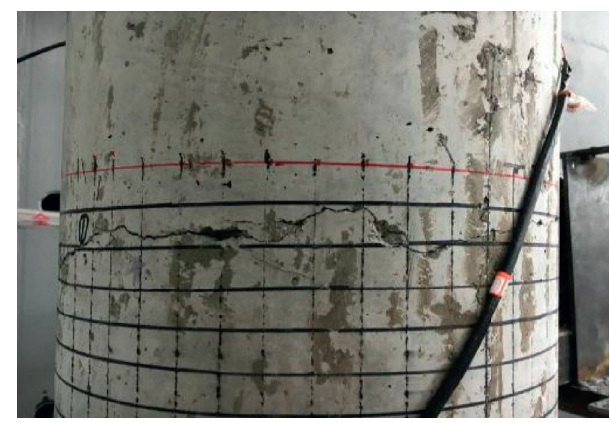

FIGURE 25: Back side damage condition of $S_{2.1}$.

TABLE 6: The number of grids of spalled concrete at the impact position.

\begin{tabular}{lcccc}
\hline Specimen & \multicolumn{4}{c}{$\begin{array}{c}\text { The initial falling height (relative height) of } \\
\text { the pendulum ball (m) }\end{array}$} \\
& 1 & 2 & 3 & 4 \\
\hline $\mathrm{S}_{4.1}$ & 1 & 4 & 17 & 44 \\
$\mathrm{~S}_{8.3}$ & 1 & 3 & 17 & 43 \\
$\mathrm{~S}_{2.1}$ & 1 & 4 & 21 & 37 \\
\hline
\end{tabular}

impact point of specimen $S_{2.1}$ kept increasing all the time, but the growth rate declined slightly after reaching the peak when the initial falling height of the pendulum ball was $3 \mathrm{~m}$.

After impact, cracks were generated on the front, back, upper, lower, and lateral sides of the impact position and on the front of the column bottom, respectively. The types and analysis of cracks are shown in Table 7. It can be seen from the analysis that serious cracks mainly appeared in two positions after the swinging ball hit the column: (1) the penetrating crack at the impact point: this type of failure was subjected to strong shear force and belonged to shear failure; (2) cracks at the bottom of the pier: as the column was far away from the impact point, it was subject to a large bending moment, and the crack developed along the side from the front, which was subject to bending damage. The comparison between the two kinds of cracks indicated that the penetrating cracks at the impact point were longer and wider at the bottom of the column due to the direct impact. However, the internal shock damage and side crack generated on both sides of the impact point were narrow and were not considered as the main cracks. According to the generation type of crack, it can be determined that the failure form of column under impact was bending shear failure. The failure process of the column was as follows: concrete spalling occurs locally at the impact position firstly, shear cracks developed through the column, and then cracks formed at the column bottom under the action of bending moment.

\section{Discussion}

5.1. Discussion on the Most Serious Failure Condition. The conditions with the most severe failure in the test are summarized as shown in Table 8. It can be seen that the most serious condition of column failure occurred when the falling height of the swing ball was $4 \mathrm{~m}$, the maximum value which had the maximum impact energy of the ball and the maximum damage to the column. With the change of the impact height from $1 / 4$ height to $3 / 8$ height and $1 / 2$ height of the column, the displacement of the column top and the growth rate increased gradually, respectively, $37.4 \%$ and $70.1 \%$, while the maximum impact force gradually declined and so did the decrease rate, respectively, $33.3 \%$ and $25 \%$. The condition with the most spalling concrete grids is $\mathrm{S}_{4.1-4}$.

By listing the conditions with the most severe damage of different impact heights, it can be known that the maximum number of concrete spalling grids and maximum displacement of column top occurred at the height of $1 / 2$ of the column, and the maximum impact force occurred at the height of $1 / 4$ of the column. Therefore, in actual engineering, these weak parts should be strengthened locally to reduce the damage.

\subsection{The Formula for Maximum Impact Force. According to} the law of conservation of energy, when a rockfall hits a bridge pier, the kinetic energy carried by the rockfall is converted into the elastic strain energy of the bridge pier, which is expressed in (4)-(7).

Kinetic energy of a rockfall is

$$
\mathrm{E}_{\mathbf{k}}=\mathbf{m g h}=\mathbf{V}_{\mathbf{s}}
$$

Elastic strain energy of a bridge pier is

$$
V_{s}=\int_{0}^{l} \frac{M^{2}(x)}{2 E I} \mathrm{~d} x=\int_{0}^{l} \frac{F_{d}^{2} x^{2}}{2 E I} \mathrm{~d} x=\frac{F_{d}^{2} l^{3}}{6 E I} .
$$

By combining the above two equations, we obtain

$$
\mathrm{mgh}=\frac{F_{d}^{2} l^{3}}{6 E I} .
$$

Therefore, the maximum impact force $\mathbf{F}_{\mathbf{d}}$ can be expressed as

$$
F_{d}=d^{2} \sqrt{\frac{3 \mathrm{mgh} E \pi}{32 l^{3}}} .
$$

In (4)-(7), $F_{d}$ refers to the maximum impact force, $E$ represents the modulus of elasticity, I is the cross-sectional moment of inertia, $M$ is the bending moment, and $d$ is on behalf of the diameter of cylindrical bridge pier.

According to Table 4, the maximum impact force calculated by the formula is compared with the measured value in the field as shown in Table 9.

In Table 9, the error range of calculated maximum impact force and measured values was $0.04 \% \sim 2.27 \%$, and the error under $1 \%$ and $1.5 \%$ made up $41.7 \%$ and $91.7 \%$, respectively, demonstrating that the error range of calculated maximum impact force and measured values was extremely slight. Equation (7) is of simple form and reliable theoretical support and can be used in engineering practice to estimate maximum impact force, which has great application values.

5.3. Influence on Pier under Axial Load. Some discrepancy exists between experimental apparatus and actual bridge conditions. For example, the experimental test device does not 
Table 7: Description of different injuries.

Perforating crack from the front and back of the point of impact

Front crack of column bottom

Internal shock damage within $20 \mathrm{~cm}$ below the impact point

Internal shock damage within $20 \mathrm{~cm}$ above the impact point

Lateral oblique crack

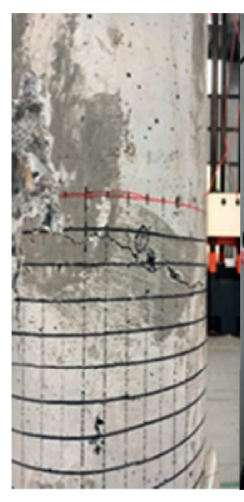

(a)

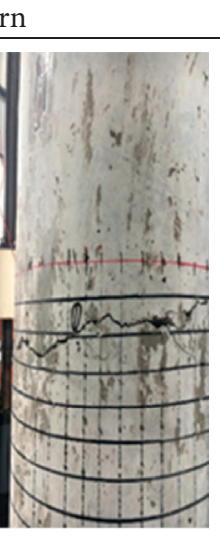

(c)
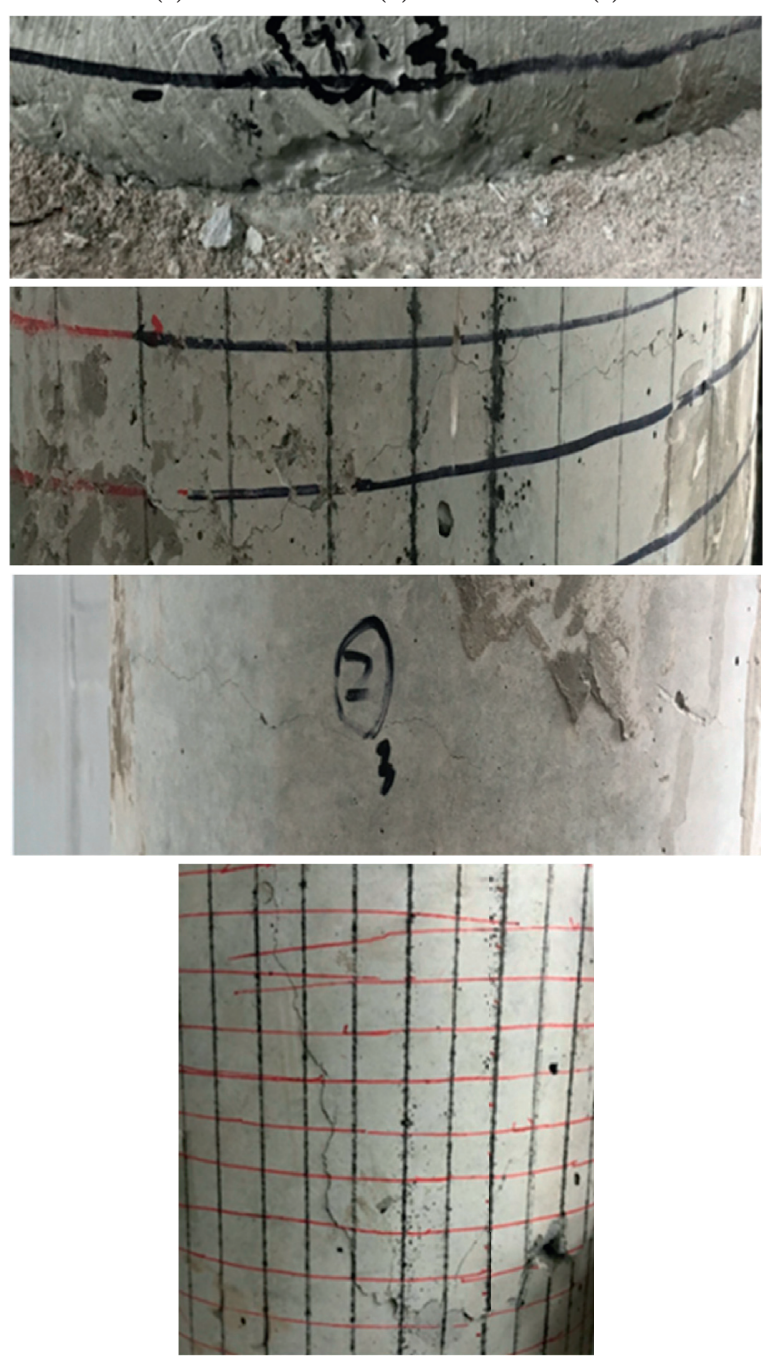

On the back of the impact position of three columns, perforating cracks appeared along the width of the model column, which developed from the back side to the front crack joint

A penetrating crack (left) and another fault crack (right) appeared on the front of the column bottom, with a width of about $0.3 \mathrm{~mm}$ and $0.2 \mathrm{~mm}$, respectively

Under impact, the model column was squeezed inside, resulting in damage and cracks in other parts of the column, such as oblique cracks $20 \mathrm{~cm}$ above and below the cracks along the impact surface

The length of the two cracks on the side of $S_{2.1-4}$ was $23.5 \mathrm{~mm}$ (left) and $37.5 \mathrm{~mm}$ (right), respectively, and the crack width was about $0.5 \mathrm{~mm}$ 
TABLE 7: Continued.

\begin{tabular}{|c|c|c|}
\hline Damage location & Observed crack pattern & Description \\
\hline Back horizontal crack & & $\begin{array}{l}\text { Horizontal cracks developed on the back below } \\
\text { the position of impact }\end{array}$ \\
\hline $\begin{array}{l}\text { Shear crack at the impact } \\
\text { position }\end{array}$ & & $\begin{array}{c}\text { Because of the strong shear force at the impact, } \\
\text { shear crack was formed }\end{array}$ \\
\hline
\end{tabular}

TABLE 8: Comparison about the most serious failure condition.

\begin{tabular}{lcccccc}
\hline Specimen & Falling height $(\mathrm{m})$ & Hitting speed $(\mathrm{m} / \mathrm{s})$ & Impact energy $(\mathrm{J})$ & $\begin{array}{c}\text { Column top } \\
\text { displacement }(\mathrm{mm})\end{array}$ & $\begin{array}{c}\text { Maximum } \\
\text { impact force }(\mathrm{kN})\end{array}$ & $\begin{array}{c}\text { The number of concrete } \\
\text { spalling grids }\end{array}$ \\
\hline $\mathrm{S}_{4 \cdot 1-4}$ & 4 & 8.85 & 2195.2 & 35.3 & 247.92 & 44 \\
$\mathrm{~S}_{8.3-4}$ & 4 & 8.85 & 2195.2 & 48.5 & 165.29 & 43 \\
$\mathrm{~S}_{2 \cdot 1-4}$ & 4 & 8.85 & 2195.2 & 82.5 & 123.96 & 37 \\
\hline
\end{tabular}

Table 9: Comparison between the calculated values and the measured values of the maximum impact.

\begin{tabular}{lcccc}
\hline Specimen & Falling height $(\mathrm{m})$ & Measured maximum impact force $(\mathrm{kN})$ & $\begin{array}{c}\text { Calculated maximum } \\
\text { impact force }(\mathrm{kN})\end{array}$ & $\begin{array}{c}\text { Absolute value of } \\
\text { error }(\%)\end{array}$ \\
\hline $\mathrm{S}_{4 \cdot 1-1}$ & 1 & 123.96 & 126.78 & 2.27 \\
$\mathrm{~S}_{4 \cdot 1-2}$ & 2 & 175.31 & 217.43 & 0.15 \\
$\mathrm{~S}_{4 \cdot 1-3}$ & 3 & 214.71 & 248.06 & 1.27 \\
$\mathrm{~S}_{4 \cdot 1-4}$ & 4 & 247.92 & 82.67 & 0.06 \\
$\mathrm{~S}_{8.3-1}$ & 1 & 82.64 & 115.52 & 0.04 \\
$\mathrm{~S}_{8.3-2}$ & 2 & 116.87 & 144.60 & 1.16 \\
$\mathrm{~S}_{8.3-3}$ & 3 & 143.14 & 166.60 & 0.02 \\
$\mathrm{~S}_{8.3-4}$ & 4 & 165.29 & 61.09 & 0.79 \\
$\mathrm{~S}_{2 \cdot 1-1}$ & 1 & 61.98 & 87.47 & 1.44 \\
$\mathrm{~S}_{2 \cdot 1-2}$ & 2 & 87.65 & 106.39 & 0.20 \\
$\mathrm{~S}_{2 \cdot 1-3}$ & 3 & 107.35 & 124.22 & 0.89 \\
$\mathrm{~S}_{2 \cdot 1-4}$ & 4 & 123.96 & & 0.21 \\
\hline
\end{tabular}

simulate the axial load exerted by the bridge deck. Therefore, the influence of rockfall on the pier under the axial load of the bridge deck should be further discussed in the following part.
5.3.1. Dynamic Response Analysis with Axial Load. Gholipour et al. [29] studied the effects of axial load on dynamic responses and failure behaviors of reinforced 
concrete (RC) columns subjected to lateral impact loading. It was found that superstructure axial load increases the impact force and the peak internal forces including the inertial force, flexural moment, and shear force. Actually, the maximum impact force, inertia force, flexural moment, and shear force of the pier will increase when considering the axial load; that is, the impact resistance performance of the pier will be enhanced.

5.3.2. Damage Analysis with Axial Load. Masi et al. [30] point out that the axial load actually imposes some constraints on the column and exerts a confining pressure on the column, thereby reducing damage. Therefore, the damage of the bridge pier with axial load when hit by falling rock may be less than the test case.

5.3.3. Further Analysis with Axial Load Ratio. With the purpose of exploring the effect of axial load on reinforced concrete columns, many studies focused on the axial load ratio (ALR), namely, column axial load/axial strength ratio, which is the indicator to evaluate the effect.

In general, ALR is usually less than 0.3 with the axial load of bridge deck, and the increase in axial load ratio enhances the shear capacity of the column and reduces its ductility $[31,32]$. However, when ALR increases to about 0.6-0.7, shear strength starts to decrease rapidly [31]. Besides, specimens under a higher ALR experienced a greater and faster deterioration in axial stiffness [33].

Therefore, the damage of the bridge pier with axial load under rockfall needs to be considered in two situations. Usually, when the ALR is small (ALR $<0.3)$, that is, when the axial load only comes from the deck, the impact resistance performance of the pier is enhanced and the damage can be reduced, but when the ALR is large (ALR > 0.6), the impact resistance performance of the pier greatly declines.

\section{Conclusions}

In this paper, a quarter scale reinforced concrete model column is designed in line with the similarity theory, while the impact force, the displacement of the column top, the time-history curve of strain dynamic response, and the damage caused to the model column are obtained by means of model test. The following conclusions are drawn:

(1) After the column took a hit, the impact force, the displacement of the column top, and the stress-strain of the column increased rapidly. After the maximum displacement of the column top, there was periodic attenuation observed with a period of $0.5 \sim 1 \mathrm{~ms}$.

(2) In case of the same impact height, with the falling height of the pendulum ball rising from $1 \mathrm{~m}$ to $4 \mathrm{~m}$, the peak value of the impact force increased, and the growth rate reached $41.4 \%, 22.5 \%$, and $15.5 \%$, respectively. The column top displacement increased by basically the same amount, but the decay period remained unchanged. According to the comparative analysis of the damage results, the damage of the impact surface was made more severe with the increase in the falling height of the pendulum ball. When the impact energy was roughly $1098 \mathrm{~J}$, cracks were observed in both the impact position and the column bottom.

(3) Under the same falling height, the impact height increased from $1 / 4$ height to $1 / 2$ height of the column, while the peak value of impact force decreased by 1.3 times and the attenuation period was extended by 1.2 times. As for damage, the lower the impact height was, the more the damage was concentrated in the local impact position. Conversely, the higher the impact position was, the more significantly the impact energy increased as the height doubled. In the meantime, the local damage and cracks manifested themselves at the bottom of the column.

(4) The vertical strain gauge near the impact position was subjected to compression while the transverse strain gauge was subjected to tension. The development of tensile strain at the bottom of the column below the impact position facilitated the occurrence of significant plastic deformation. Compressive strain developed at the back of the column bottom, and the minimum strain developed on the top of the column, which was consistently in the elastic stage during the test.

(5) After the impact of the pendulum ball, first, concrete sag and spalling developed in the local part of the collision position of the column, followed by two major cracks. Second, the crack resulting from bending failure developed at the bottom of the column. The failure mode of column impacted by the swing ball is shear-flexural failure.

(6) In practice, it is recommended that preventative measures are taken for protecting the weak positions such as $1 / 2$ height and $1 / 4$ height of bridge pier, so as to minimize the potential damage caused by rockfalls. In addition, a theoretical formula is proposed for estimating the maximum impact force.

(7) With the axial load of the bridge deck, the axial load ratio is usually small, the performance of the pier in withstanding impact under rockfall is enhanced, and the damage is reduced. The axial load of the deck imposes some constraints on the pier, thus reducing concrete damage.

\section{Data Availability}

The data used to support the findings of this study were obtained by our experiments and are included within the article.

\section{Conflicts of Interest}

The authors declare that they have no conflicts of interest. 


\section{Acknowledgments}

The study was supported by National Nature Science Foundation of China (Grant no. 41472325), Zigong Science and Technology Bureau Project (2019RKX02), Talent Introduction Project Fund of Sichuan University of Science and Engineering (2018RCL08), Opening Project of Sichuan Province University Key Laboratory of Bridge Non-destruction Detecting and Engineering Computing (2018QZJ02 and 2019QZJ04), Scientific Research Foundation of Graduate School of Southeast University (Grant no. YBJJ 1844), and Postgraduate Research and Practice Innovation Program of Jiangsu Province (Grant no. KYCX17_0130).

\section{References}

[1] A. Q. Bhatti, "Computational modeling of energy dissipation characteristics of expanded polystyrene (EPS) cushion of reinforce concrete (RC) bridge girder under rockfall impact," International Journal of Civil Engineering, vol. 16, no. 11, pp. 1635-1642, 2018.

[2] O. Mavrouli and J. Corominas, "Vulnerability of simple reinforced concrete buildings to damage by rockfalls," Landslides, vol. 7, no. 2, pp. 169-180, 2010.

[3] R. Xie, W. Fan, B. Liu, and D. Shen, "Dynamic behavior and vulnerability analysis of bridge columns with different crosssectional shapes under rockfall impacts," Structures, vol. 26, pp. 471-486, 2020.

[4] X. Zhang, Z. P. Wen, R. Liu, L. H. Ruan, and X. Z. Li, "Dynamic responses of a ballastless track bridge under debris flow impacts," Journal of Railway Engineering Society, vol. 35, no. 1, pp. 70-77, 2018.

[5] İ. Keskin, "Evaluation of rock falls in an urban area: the case of Boğaziçi (Erzincan/Turkey)," Environmental Earth Sciences, vol. 70, no. 4, pp. 1619-1628, 2013.

[6] T. Noguchi and T. Fujii, "Minimizing the effect of natural disasters," Japan Railway \& Transport Review, vol. 23, pp. 52-59, 2000.

[7] L.-W. Wei, H. Chen, C.-F. Lee et al., "The mechanism of rockfall disaster: a case study from Badouzih, Keelung, in northern Taiwan," Engineering Geology, vol. 183, pp. 116-126, 2014.

[8] B. Ren and S. Li, "Meshfree simulations of plugging failures in high-speed impacts," Computers \& Structures, vol. 88, no. 1516, pp. 909-923, 2010.

[9] W. Fan and P. Qiao, "Vibration-based damage identification methods: a review and comparative study," Structural Health Monitoring, vol. 10, no. 1, pp. 83-111, 2011.

[10] V. U. Minorsky, An Analysis of Ship Collisions with Reference to Protection of Nuclear Power Plants, Sharp (George G.) Inc., New York, NY, USA, 1958.

[11] M. W. Whitney, I. E. Harik, J. J. Griffin, and D. L. Allen, "Barge collision design of highway bridges," Journal of Bridge Engineering, vol. 1, no. 2, pp. 47-58, 1996.

[12] D. Y. Shi and Y. C. Li, Explicit Dynamic Analysis Based on ANSYS/LS-DYNA8. 1, pp. 200-210, Tsinghua University Press, Beijing, China, 2005.

[13] K. A. Reckling, "Mechanics of minor ship collisions," International Journal of Impact Engineering, vol. 1, no. 3, pp. 281-299, 1983.
[14] S. He, S. Yan, Y. Deng, and W. Liu, "Impact protection of bridge piers against rockfall," Bulletin of Engineering Geology and the Environment, vol. 78, no. 4, pp. 2671-2680, 2019.

[15] Y. E. Lu and L. M. Zhang, "Analysis of failure of a bridge foundation under rock impact," Acta Geotechnica, vol. 7, no. 1, pp. 57-68, 2012.

[16] Z. X. Yu, L. Y. Zhang, Y. N. Zhao, and T. Wei, "Effectiveness analysis on the protection measures for the mountain bridge piers against rockfall," Applied Mechanics and Materials, vol. 226-228, pp. 1683-1688, 2012.

[17] S. Haris and J. Amdahl, "Analysis of ship-ship collision damage accounting for bow and side deformation interaction," Marine Structures, vol. 32, pp. 18-48, 2013.

[18] D. Servis, M. Samuelides, T. Louka, and G. Voudouris, "Implementation of finite-element codes for the simulation of ship-ship collisions*," Journal of Ship Research, vol. 46, no. 04, pp. 239-247, 2002.

[19] Y. He, W. Jin, A. Zhang, and J. Wu, "Nonlinear collision simulation on dynamic interaction between ship-bridge," Journal of Zhejiang University (Engineering Science), vol. 42, no. 6, pp. 1065-1070, 2008.

[20] J. Liu and Y. Gu, "Simulation of ship-bridge head-on collision based on finite element model of whole ship-bridge," Engineering Mechanics, vol. 20, no. 5, pp. 155-162, 2003.

[21] J.-P. Mougin, P. Perrotin, M. Mommessin, J. Tonnelo, and A. Agbossou, "Rock fall impact on reinforced concrete slab: an experimental approach," International Journal of Impact Engineering, vol. 31, no. 2, pp. 169-183, 2005.

[22] G. Plantard and M. Papini, "Mechanical and electrical behaviors of polymer particles. Experimental study of the contact area between two particles. Experimental validation of a numerical model," Granular Matter, vol. 7, no. 1, pp. 1-12, 2005.

[23] S. Kawahara and T. Muro, "Effects of dry density and thickness of sandy soil on impact response due to rockfall," Journal of Terramechanics, vol. 43, no. 3, pp. 329-340, 2006.

[24] B. Pichler, C. Hellmich, and H. A. Mang, "Impact of rocks onto gravel design and evaluation of experiments," International Journal of Impact Engineering, vol. 31, no. 5, pp. 559$578,2005$.

[25] V. Labiouse, F. Descoeudres, and S. Montani, "Experimental study of rock sheds impacted by rock blocks," Structural Engineering International, vol. 6, no. 3, pp. 171-176, 1996.

[26] S. He, Y. Wu, and X. Li, "Research on restitution coefficient of rock fall," Rock and Soil Mechanics, vol. 30, no. 3, pp. 623-627, 2009.

[27] S. Jun, H. Siming, and W. Yong, "Present research status and development trend of rockfall hazards," Journal of Catastrophology, vol. 4, p. 122, 2008.

[28] X. Zhang, X. Wang, W. Chen, Z. Wen, and X. Li, "Numerical study of rockfall impact on bridge piers and its effect on the safe operation of high-speed trains," Structure and Infrastructure Engineering, vol. 17, no. 1, pp. 1-19, 2020.

[29] G. Gholipour, C. Zhang, and A. A. Mousavi, "Effects of axial load on nonlinear response of RC columns subjected to lateral impact load: ship-pier collision," Engineering Failure Analysis, vol. 91, pp. 397-418, 2018.

[30] A. Masi, G. Santarsiero, A. Mossucca, and D. Nigro, "Influence of axial load on the seismic behavior of RC beam-column joints with wide beam," Applied Mechanics and Materials, vol. 508, pp. 208-214, 2014.

[31] M. A. Al-Osta, U. Khan, M. H. Baluch, and M. K. Rahman, "Effects of variation of axial load on seismic performance of 
shear deficient RC exterior BCJs," International Journal of Concrete Structures and Materials, vol. 12, no. 1, p. 46, 2018.

[32] X. Zhou and J. Liu, "Seismic behavior and shear strength of tubed RC short columns," Journal of Constructional Steel Research, vol. 66, no. 3, pp. 385-397, 2010.

[33] R. K. L. Su and S. M. Wong, "Seismic behaviour of slender reinforced concrete shear walls under high axial load ratio," Engineering Structures, vol. 29, no. 8, pp. 1957-1965, 2007. 